\title{
Can global models provide insights into regional mitigation strategies? A diagnostic model comparison study of bioenergy in Brazil
}

\author{
Alexandre C. Köberle ${ }^{1,2}$. Vassilis Daioglou ${ }^{3,4} \cdot$ Pedro Rochedo $^{2} \cdot$ André F. P. Lucena $^{2}$. \\ Alexandre Szklo ${ }^{2}$. Shinichiro Fujimori ${ }^{5,6}$. Thierry Brunelle ${ }^{7}$. Etsushi Kato ${ }^{8}$. \\ Alban Kitous $^{9} \cdot$ Detlef P. van Vuuren ${ }^{3,4} \cdot$ Roberto Schaeffer $^{2}$
}

Received: 3 July 2019 / Accepted: 2 October 2021 / Published online: 4 January 2022

(C) The Author(s) 2021

\begin{abstract}
The usefulness of global integrated assessment model (IAM) results for policy recommendation in specific regions has not been fully assessed to date. This study presents the variation in results across models for a given region, and what might be behind this variation and how model assumptions and structures drive results. Understanding what drives the differences across model results is important for national policy relevance of global scenarios. We focus on the use of bioenergy in Brazil, a country expected to play an important role in future bioenergy production. We use results of the Stanford University Energy Modeling Forum's 33rd Study (EMF-33) model comparison exercise to compare and assess projections of Brazil's bioenergy pathways under climate mitigation scenarios to explore how 10 global IAMs compare to recent trends in the country. We find that, in their current form, global IAMs have limited potential to supply robust insights into regional mitigation strategies. Our results suggest fertile ground for a new research agenda to improve regional representation in global IAMs with improved spatial and technological resolutions.
\end{abstract}

Keywords Integrated assessment models (IAMs) $\cdot$ Global models $\cdot$ Regional mitigation strategies

\section{Introduction}

Integrated assessment models (IAMs) are tools designed to answer questions concerning the future development of environmental and sustainability issues. They do this by describing the interactions between human activities (such as energy use and agriculture) and environmental factors such as land-cover and climate systems. Based on this, they can help

This article is part of the Topical Collection on "Assessing Large-scale Global Bioenergy Deployment for Managing Climate Change (EMF-33)" edited by Steven Rose, John Weyant, Nico Bauer, Shinichiro Fuminori, Petr Havlik, Alexander Popp, Detlef van Vuuren, and Marshall Wise

Alexandre C. Köberle

a.koberle@imperial.ac.uk

Extended author information available on the last page of the article 
investigate climate mitigation strategies such as those set out in the Paris Agreement. These strategies often show a critical role for bioenergy (Creutzig et al. 2015). This is an important finding as the land-use impacts of biomass production may negatively affect other development indicators such as food security, biodiversity, water resources and ecosystem services (Hasegawa et al. 2018; IPCC, 2019; Rogelj et al. 2018a, b; Searchinger et al. 2015). At the global scale, quite some attention has been paid to the role of bioenergy in climate change mitigation efforts and the land-use consequences (Bauer et al. 2018; Meller et al. 2015; Rogelj et al. 2018a, b; Rose et al. 2014). However, very little attention has been paid to developments in specific regions in the context of global developments. Looking at the regional outcomes is important for two reasons: first, they can help to provide insights for national policymaking, especially since bioenergy is a limited resource; second, looking at specific regions can help us understand if global IAMs deliver reasonable pathways for individual regions. This paper examines the second point to inform whether IAMs can be relied upon to fulfil the first.

For several reasons, Brazil plays an important role in global bioenergy production. First, the country is currently a major agricultural producer and features as a major international supplier for agricultural products in the coming decades, including bioenergy feedstocks, both in government and industry projections (FIESP 2015; MAPA 2013; OECD-FAO 2015; USDA 2020) and future scenario studies (Matzenberger et al. 2015; Octaviano et al. 2014). Second, the country is home to one of the most successful cases of bioenergy implementation in the world, with bioenergy having supplied over $20 \%$ of the country's annual primary energy consumption for decades (EPE 2019). The PROALCOOL program started in the 1970s in response to the international oil-shocks and grew over the decades through government support policies and technological innovations that kept sugarcane ethanol competitive through oil-price fluctuations (Goldemberg et al. 2004; OECD-FAO 2015). More recently, Brazil launched a new National Biofuel Policy - the RenovaBio program — establishing a carbon credits market for biofuels (Klein et al. 2019; Salina et al. 2020). The Brazilian Biodiesel Program brought mandatory rates of B10 (10\% by volume) in 2018, B12 in 2020 and B13 in March 2021 to all mineral diesel sold in the country (ANP 2018, 2021). Drawing on the existing bioenergy know-how to exploit the country's enormous bioenergy production potential makes it a potential leader in future bioenergy technological innovations for advanced biofuels (Carvalho et al. 2016; Tagomori et al. 2019). Finally, firewood and charcoal are still used extensively, not just in the residential sector (Mazzone et al. 2021) but also in the agricultural sector (e.g. heat for grain drying), specific industrial sectors (e.g. pulp \& paper, ceramics and food \& beverages), and in the iron $\&$ steel sector as both an energy source and a reducing agent (EPE 2015).

However, the expansion of Brazilian agriculture over the last half-century has brought environmental impacts in the form of land-use change (LUC), deforestation, and greenhouse gas (GHG) emissions from the agricultural, forestry, and land-use sectors (AFOLU), along with negative impacts on livelihoods and equity dimensions (Hunsberger et al. 2014; Sonter et al. 2014). Conversely, some studies have highlighted the economic benefits of sugarcane to certain localities in Brazil (Assunção et al. 2016) and the potential for bioenergy production on land made available by livestock intensification (Havlik et al. 2014; Köberle et al. 2020; Strassburg et al. 2014). Potential risks from increased production and use of bioenergy, which are well-documented globally (Gasparatos et al. 2011), call for measures to mitigate them (Alexandratos and Bruinsma 2012; Hunsberger et al. 2014). However, such measures rely on good governance and firm policies, for which Brazil has a mixed record (Rochedo et al. 2018; Soares-filho et al. 2014, 2016). 
The overarching goal of this study is to present the variation in bioenergy projections across models for a specific region and understand what might be behind this variation. We use the results of the Stanford University Energy Modeling Forum's 33rd Study (EMF-33) model comparison exercise (Rose et al. 2020; Bauer et al. 2018; Rose et al. 2021) to compare and assess projections of Brazil's bioenergy pathways under climate mitigation scenarios. Specifically, we focus on global model projections concerning the role of bioenergy in Brazil's future energy and land systems, and implications for the country's GHG emissions and land use. Understanding what drives the differences across model results is important for national policy relevance of global scenarios (Biggs et al. 2007; van Ruijven et al. 2013). By focusing on Brazil, the analysis aims to cut through generalisations inherent in global assessments, zoom in on specific assumptions and results, compare them to current trends, and explore whether global IAMs can provide robust insights to specific regions.

In Sect. 2, we explain the methodology and describe the models and scenarios included in the analysis. Section 3 reports the model projections for Brazil concerning primary energy demand, the role of bioenergy, land use trends, and greenhouse gas emissions. This is followed by a discussion (Sect. 4) and the conclusions (Sect. 5).

\section{Methods}

Of the 12 models participating in the EMF-33 study, we use those that have Brazil represented as a separate region. We examine key results in primary energy, biomass production in agriculture, land-use change, the mix of biomass-based energy carriers, and emissions from both energy and AFOLU sectors.

To assess how well the IAMs represent the Brazil region and their usefulness in providing regional policy advice, we compare the model results to available information on recent Brazilian trends. Current trends are assessed through a review of peer-reviewed literature and grey literature, reports from the Brazilian government and national research agencies, academic theses, and interaction with experts. Data sources to provide historical trajectories of key variables include national research institutes, government agencies and universities, and are listed along with the figures and analyses they informed. Current energy trends are taken from literature and the national energy balance (EPE 2019), while agricultural production, area and yields come from Conab (2017), as noted in the text and figures.

\subsection{Models analysed}

The models participating in EMF-33 include very different representations of the energy and land-use systems (see Table S1 in the Supplemental Material, which summarises the main characteristics of the models analysed). Of the ten models included here, six follow a recursive-dynamic approach and four use intertemporal optimisation. Representation of land use varies not only in terms of the land cover types but also in terms of the assumptions related to land-use dynamics. This includes the competition between different types of land use and the possibility to intensify agricultural production (Rose et al. 2021).

While there is significant inter-model variation in the representation of technologies and feedstocks and the characterisation of first- and second-generation routes, there is limited intra-model regional differentiation (Daioglou et al. 2020a, b; Hanssen et al. 2020a, b; Rose et al. 2021). That is, these models select from a global portfolio of options and 
Table 1 Scenarios analysed in this study

\begin{tabular}{lll}
\hline Scenario & $\begin{array}{l}\mathrm{CO}_{2} \text { Budget } \\
(2011-2100)\end{array}$ & Technology restrictions \\
\hline Baseline & None & No restrictions \\
Mitig-Full & 1000 & No restrictions \\
Mitig-No BECCS & 1000 & No BECCS \\
Mitig-No Adv Fuel & 1000 & No 2nd-gen biofuels \\
\hline
\end{tabular}

may not represent specific options relevant for Brazil specifically. The COFFEE model (Rochedo 2016) is an interesting exception as it was developed to study how the country may participate in global efforts to mitigate climate change. As such, its technology and feedstock options, as well as $\mathrm{CO}_{2}$ storage logistics and costs, reflect some Brazilian specificities not present in other models. Importantly, it explicitly models the sugarcane chain from the agricultural phase through to sugar, ethanol and bioelectricity production in purpose-built mills and distilleries, reflecting the current situation in Brazil.

On the other hand, COFFEE lacks a spatially explicit representation of land use and relies instead on national average values for the land use parameters. Of the models included here, GCAM, IMAGE, IMACLIM-NLU, AIM/CGE, are either spatially explicit models themselves or have gridded land-use modules. The POLES version used in EMF33 was not yet linked to a spatial land-use model, but a soft link with GLOBIOM has since been developed. All models include the possibility of carbon capture and storage technology with bioelectricity, while for 2nd generation fuels, this is limited to AIM/ CGE, COFFEE, GCAM, IMAGE, and POLES. Only AIM/CGE, COFFEE, and IMAGE include 1st generation fuels with CCS. The date at which CCS becomes available varies across models but is always between 2020 and 2030 (Daioglou et al. 2020a, b).

\subsection{Scenario choices}

In this study, we have focused on a few key scenarios from the EMF-33 study (Table 1) that focused on bioenergy demand - see Rose et al. (2020) and Bauer et al. (2018) for additional scenario specification details. Based on an SSP2 baseline (Fricko et al. 2016; Popp et al. 2017), these scenarios' main drivers are GDP and population, which for Brazil are expected to continue growing in the next decades, with the population peaking around mid-century (Dellink et al. 2015; KC and Lutz 2017). The resulting higher income levels bring higher demand for energy, food and fibre. In addition to the baseline, we explore three variations of scenarios consistent with keeping temperature increase to below $2{ }^{\circ} \mathrm{C}$ over the pre-industrial period with a $>66 \%$ chance (global 1,000 $\mathrm{Mt}^{\mathrm{CO}}$ budget) (IPCC 2014). The scenarios assume limits on global carbon budgets, applied to cumulative global energy and industry $\mathrm{CO}_{2}$ emissions from 2011 to 2100 (see Bauer et al. 2018). Each model achieves the carbon budget by imposing a constraint on cumulative emissions, setting a global emission or $\mathrm{CO}_{2}$ price trajectory that satisfies the budget. As EMF-33 focuses on bioenergy in the energy system, the budget does not include $\mathrm{CO} 2$ emissions from the landuse sector and non-CO2 GHG emissions, but these emissions are priced according to the resultant $\mathrm{CO}_{2}$ price using $\mathrm{CO} 2$-equivalent emission taxes.

The first scenario variation (Mitig-Full scenario) has no technological restrictions on reaching the $\mathrm{CO}_{2}$ budget. In order to explore the implications of technology availability 


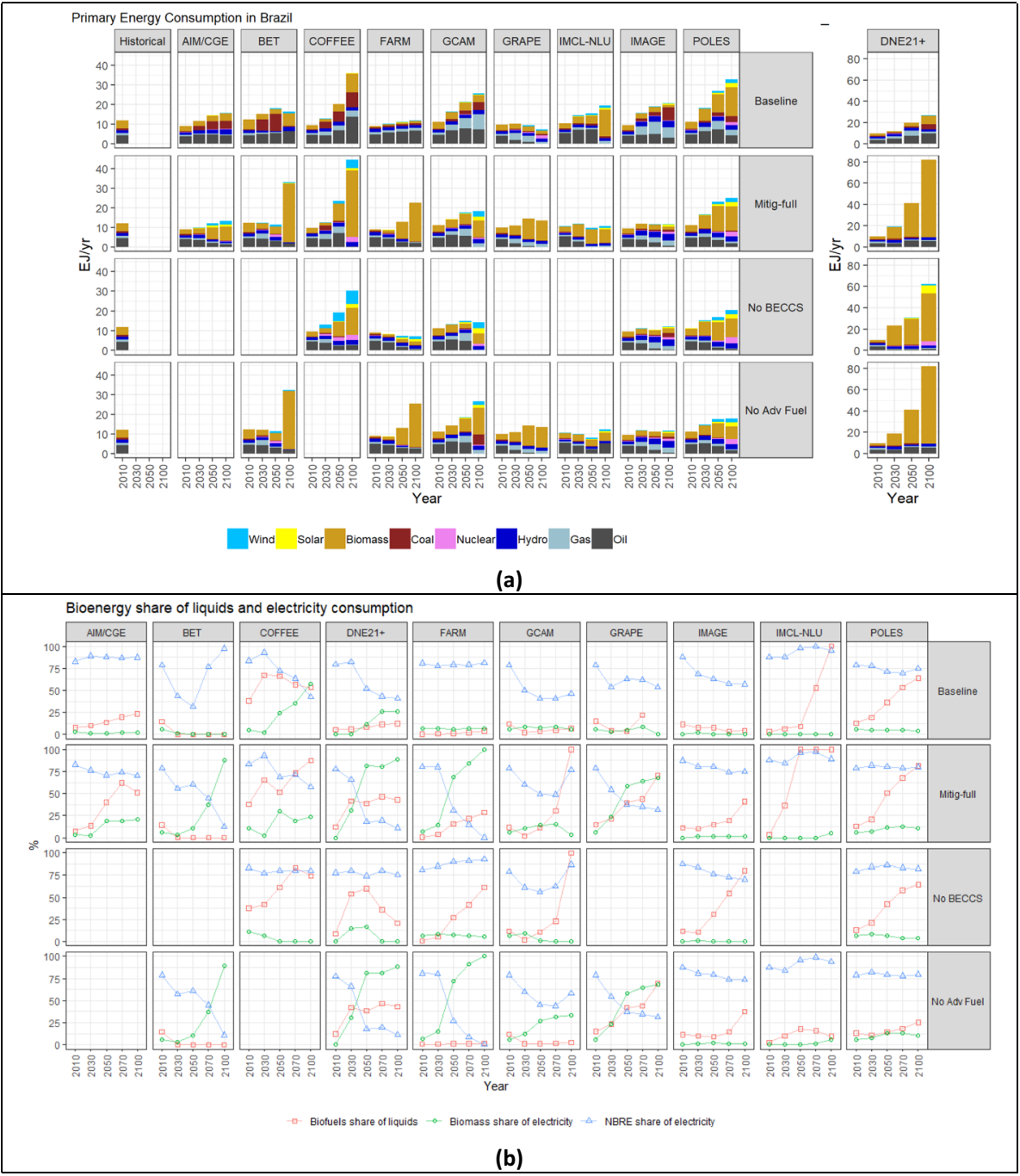

Fig. 1 Primary energy consumption and share of bioenergy in secondary energy consumption in Brazil. Panel (a) primary energy consumption in Brazil: historical (left column), and model results (DNE21 + shown with separate scale). Panel (b), bioenergy consumption share of total electricity and liquid fuels consumption in Brazil; Non-biomass renewable energy (NBRE) share of electricity. Source: Historical data from Brazil's National Energy Balance (EPE 2015). Historical biomass consumption includes firewood, black liquor and sugarcane products (juice, bagasse and molasses). For historical bioenergy carriers, see Figure S1

on global and Brazil's bioenergy and land-use projections and mitigation efforts, we assess a case where no Bioenergy with Carbon Capture and Storage (BECCS) is available (the No-BECCS scenario), and one where no advanced (2nd generation) biofuels are available (the No Adv Fuel scenario). 


\section{Results}

\subsection{Primary energy trends and implications for bioenergy demand}

Figure 1a shows that 2010 values vary across models, although the mix is broadly in line with that reported by the official National Energy Balance (BEN) of Brazil (EPE 2019). This variation stems from 2010 being a modelled year in most models (the base year being much earlier) and calibration of historical years being done to various data sources like the IEA energy balances (IEA 2020). Still, 2010 values are broadly in line with the observed current energy mix in Brazil, showing low coal and gas use due to the high share of renewables. In contrast, projections vary widely in the Baseline scenario both in terms of total Primary Energy Consumption (PEC) and of the share of different primary energy resources. Across models, in the absence of climate policies fossil fuels generally increase towards 2050, with some models choosing coal while others opt for more oil and gas. This general increase and varying mix in the use of fossil fuels in the absence of climate constraints is in line with other model inter-comparison studies for Brazil (Herreras Martínez et al. 2015; Köberle et al. 2015, 2018, 2020; Lucena et al. 2016). Bioenergy features in the baseline of all models albeit to varying degrees. For a more detailed view of each energy carrier projection, see Figure S2 and for primary bioenergy carriers Figure S4.

Mitigation scenarios across models include a reduction in PEC through increased efficiency (GCAM, IMACLIM-NLU, IMAGE), and changes to projected fuel mix by replacing oil and coal mainly with biomass and a combination of wind and gas in power generation. Across models, bioenergy makes up 23-74\% and 13-91\% of PEC in 2050 and 2100, respectively. For comparison to historical data by primary energy source across models, see Figure S2.

Figure $1 \mathrm{~b}$ shows the share of bioenergy in liquid fuels and power generation, as well as the electricity share provided by non-biomass renewable energy (nBRE) across models. The high current share of hydropower shows as a high share of nBRE, which in most models decreases in mitigation scenarios as bioenergy deployment grows to meet climate targets (see Figure S3 for bioenergy use per feedstock across models). The more detailed representation of the existing Brazilian sugarcane chain in COFFEE (including sugarcane bagasse fired-electric power generation) explains its high share of biofuels in liquids and bioelectricity in the power mix, including in the baseline (Figure S3).

While models generally agree that bioenergy should play an important role in the mitigation efforts of Brazil throughout the twenty-first century, the conversion technologies deployed in the country vary across models (Fig. 1b). Some models deploy bioenergy primarily to decarbonise electricity (BET, and FARM), others to decarbonise transportation through bioliquids (AIM, COFFEE, GCAM, IMACLIM-NLU, IMAGE and POLES), while others have a more mixed approach (DNE21 + and GRAPE primarily, but AIM and COFFEE to a lesser extent). Those that project significant bioenergy use in Brazil - AIM, COFFEE, GRAPE and POLES - deploy both bioelectricity and a combination of 1st and 2nd generation bioethanol and biodiesel (Figure S3). It is worth noting that bioenergy production in 2010 in Brazil comprised of 0.621 EJ of 1st generation ethanol, 0.113 EJ of 


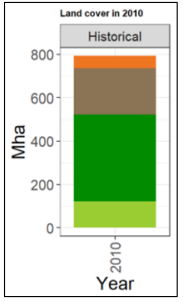

(a)

\begin{tabular}{|l|r|}
\hline \multicolumn{2}{|l|}{\begin{tabular}{l} 
Land Cover Type \\
Area in 2010 (Mha) \\
\hline Forest
\end{tabular}} \\
\hline Savanna & 400.3 \\
\hline Pasture & 122.2 \\
\hline Cropland & 213.4 \\
\hline
\end{tabular}

(b)

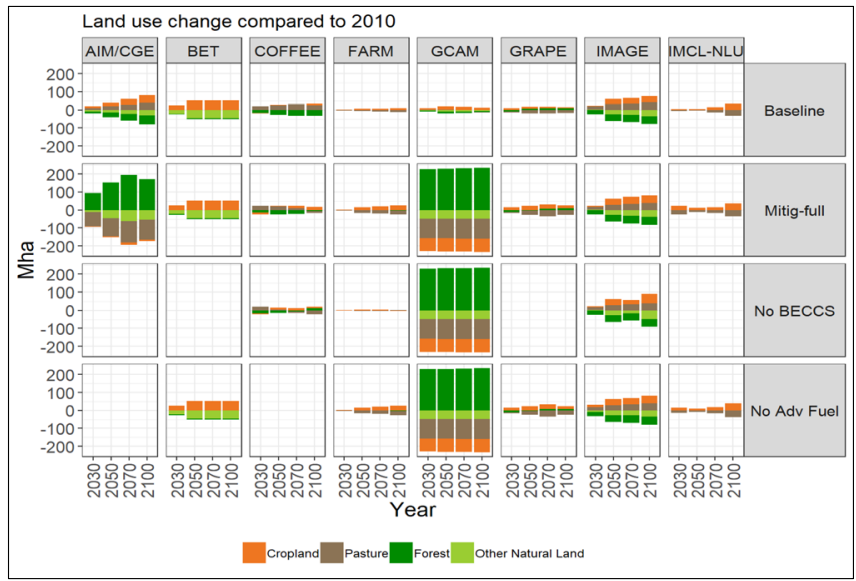

(c)

Fig. 2 Land cover and land use change in Brazil. (a) and (b) Land Cover in Brazil in 2010 (source: based on Köberle, 2018). (c) Land use change in Brazil across models and scenarios for years 2030, 2050 and 2100, relative to 2010. Bars indicate the difference between the area of a given land cover type in the labelled year and the base year 2010. Missing plots indicate infeasibility. FARM and IMACLIM-NLU do not allow changes to area of natural vegetation. The two omitted models either do not include endogenous land use change (POLES) or have spatial aggregation that does not allow reporting for Brazil (DNE21 +)

biodiesel, and 0.161 EJ of bioelectricity (EPE 2019), with very little 2nd generation ethanol being produced in the country. ${ }^{1}$

\subsection{Land use change and agriculture}

Similar to energy use, land use cover results vary widely across models (both in terms of volume and type of land use changes), indicating there is much variability in the way models project and allocate land use change. Figure 2 shows the difference in area within Brazil of a given land cover type relative to 2010 for the years 2030, 2050 and 2100. Under these scenario specifications, some models are particularly responsive to emissions constraints in the way they allocate land use change (AIM/CGE and GCAM) and tend to favour afforestation, with GCAM deploying the whole afforestation potential as soon as it is possible. In the Mitig-Full scenario, AIM/CGE and GCAM project up to 200 Mha of afforestation by the end of the century. This increase in forest area is enabled by a reduction in pasture and cropland area and conversion of other natural lands (read savannas in Brazil). Pasture area reduction amounts to some 100 Mha, about half of the current pasture area in Brazil, which implies a doubling of pasture productivity if meat production levels are to be maintained.

Other models project a much smaller reallocation of land uses in Brazil, mostly showing an increase in cropland to accommodate increased food and bioenergy production for local consumption or export, leading to about 100 Mha of natural land conversion. IMAGE shows a very subdued response to the different emissions and technology constraints, with forest and pasture areas not changing much across scenarios and the increase in cropland accommodating bioenergy expansion. It is also interesting to

1 Two plants currently produce $2 \mathrm{G}$ ethanol from sugarcane products with combined capacity for $102 \mathrm{ML} /$ year, a small fraction of the 2.5 GL/year produced in the country (EPE 2020). 


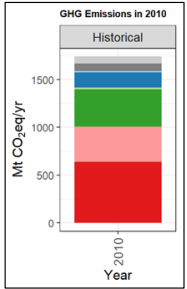

(a)

\begin{tabular}{|l|r|}
\hline \multicolumn{2}{|l|}{$\begin{array}{l}\text { GHG Emissions in } 2010 \\
\text { (MtCO2eq/year) }\end{array}$} \\
\hline $\mathrm{CO}_{2}$ AFOLU & 635.7 \\
\hline $\mathrm{CO}_{2}$ Energy & 367.1 \\
\hline $\mathrm{CO}_{2}$ Ind Process & 79.8 \\
\hline $\mathrm{CH}_{4}$ AFOLU & 394.7 \\
\hline $\mathrm{CH}_{4}$ Energy \& Ind Proc & 18.4 \\
\hline $\mathrm{N}_{2} \mathrm{O}$ Energy \& Ind Proc & 9.9 \\
\hline $\mathrm{N}_{2} \mathrm{O}$ AFOLU & 159.7 \\
\hline GHGs Waste & 75.5 \\
\hline
\end{tabular}

(b)

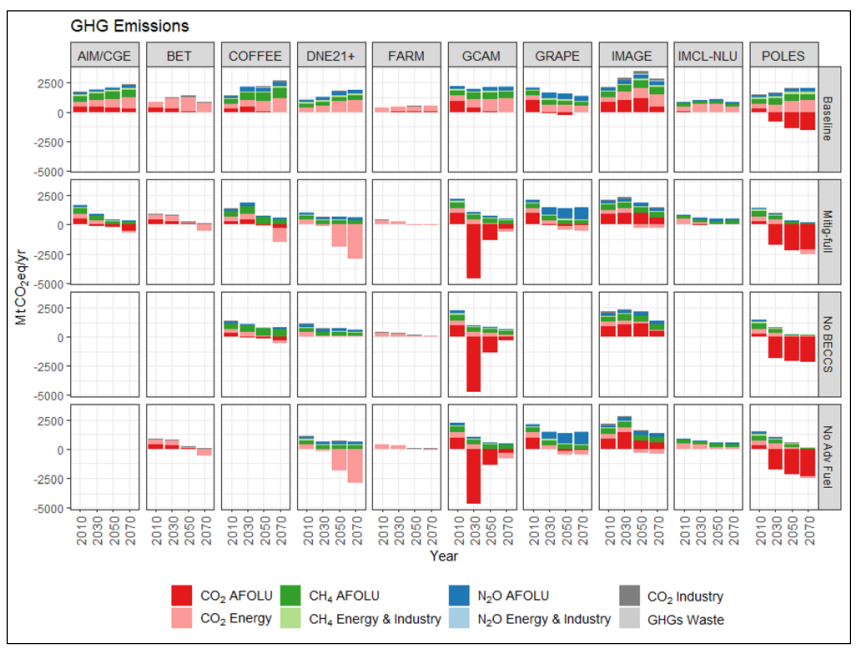

(c)

Fig. 3 Greenhouse gas emissions for Brazil. a Brazil historical GHG emissions for year 2010. Source: Based on SEEG (2019). b Same as (a) but in tabular form. (c) GHG emissions for Brazil as projected by the models in EMF33 included in this study

note that IMAGE projects an increase in pasture area (despite concurrent increases in livestock intensity), while all other models show a decrease. IMAGE projects a $\approx 10 \%$ increase in pasture area, and an almost $100 \%$ increase in livestock production, with the region becoming a major food (and bioenergy) exporter thanks to massive increases in livestock intensity, and a loss of about 10-20\% of natural lands. IMACLIM-NLU and GRAPE project transitions from pastures to cropland, with GRAPE showing some net forest growth at the expense of pastures. Natural forest area in FARM and IMACLIMNLU is exogenously determined, and remains constant throughout the period of analysis, so the only changes possible are between cropland and pasture ${ }^{2}$ (Leblanc et al., this issue).

An important aspect of projected land-use strategies concerns the projected international trade of food and bioenergy, and modelled competitiveness of Brazil vis-a-vis other regions. This is highlighted by the contrasting strategies of GCAM and IMAGE, where GCAM uses afforestation in Brazil to provide large negative emissions at the expense of bioenergy and food production with Brazil becoming an importer of bioenergy (Daioglou et al. 2020a, b). In contrast, IMAGE intensifies and expands production of both food and bioenergy in Brazil, aided by its relatively higher yields (Section S6), becoming a net exporter to decarbonise the energy systems and free up land in other regions. A discussion on the global context of the projections is available in Sect. 4.1.3

\footnotetext{
${ }^{2}$ Although sensitivity analyses are available for IMACLIM-NLU where forest area is allowed to change (Leblanc et al., this issue). In FARM it is exogenous only (Ron Sands, personal email communication, May 20, 2019).
} 
Finally, the land use dynamics shown here are affected by how agricultural productivity (yields) is represented in models, which varies widely with all models showing increased yields over the century. For more details on agricultural yields implementation and projections in these scenarios, see Section S6.

\subsection{GHG emissions}

Figure 3 shows results for emissions of the main GHGs. Results show emissions also vary across models, not only in the gases and sources represented, but also in the level of emissions and the use of negative emissions. Some models account for $\mathrm{CO}_{2}$ only (BET, ${ }^{3}$ $\mathrm{FARM}^{4}$ ), while others have normative assumptions about land use dynamics (Sect. 3.2) that affect the resulting emissions.

Emissions of non- $\mathrm{CO}_{2}$ gases also vary across models that represent them, although the variation is greater for methane $\left(\mathrm{CH}_{4}\right)$ than for nitrous oxide $\left(\mathrm{N}_{2} \mathrm{O}\right)$. Methane emissions from enteric fermentation are a major contributor to GHG emissions in Brazil today and are projected to become the dominant source as $\mathrm{CO}_{2}$ emissions are mitigated (Köberle et al. 2020), a result shown here as well across most models. Nitrous oxide emissions are more consistent across models with the exception of GRAPE, which shows much higher emissions of $\mathrm{N}_{2} \mathrm{O}$ from agriculture.

CDR use also varies considerably across models in both quantity and sources, with some showing Brazil either approaching carbon neutrality (AIM/CGE, IMAGE), while others project it to become a global sink for $\mathrm{CO}_{2}$ through negative emissions (COFFEE, GCAM, POLES). COFFEE, GCAM and POLES show negative emissions at some point during the time period, with GCAM earlier in the mitigation period (due to large scale afforestation early on), COFFEE and POLES more towards the end. This negative emissions profile comes from BECCS (COFFEE) and afforestation (GCAM, POLES). Some CCS from fossil energy sources also plays a part in decarbonising energy systems.

\section{Discussion}

Understanding what drives the differences across model results is important for the relevance of global scenarios for national policymaking (Biggs et al. 2007; van Ruijven et al. 2013). Results presented here show significant variation across models and for each scenario for energy, land use, and GHG emissions. This may indicate a wealth of options and alternative pathways for Brazil's future climate mitigation but could also just reflect the structural differences between the models.

IAMs arrive at a solution through endogenous adjustments to deployment levels of alternative technologies. These technologies' characteristics (such as costs) are endogenously calculated, often based on outputs from other technologies within the models. There is a high degree of dependency across sectors and at different points in the value chain of a particular commodity. As noted in Daioglou et al. (2020a, b), investment decisions in IAMs are not based solely on costs but also consider transitional and system integration factors, the energy demand context, as well as market dynamics such as constraints on capacity

\footnotetext{
3 Personal email communication, Junichi Tsutsui, May 16, 2019.

${ }^{4}$ Personal email communication, Ron Sands, May 20, 2019.
} 


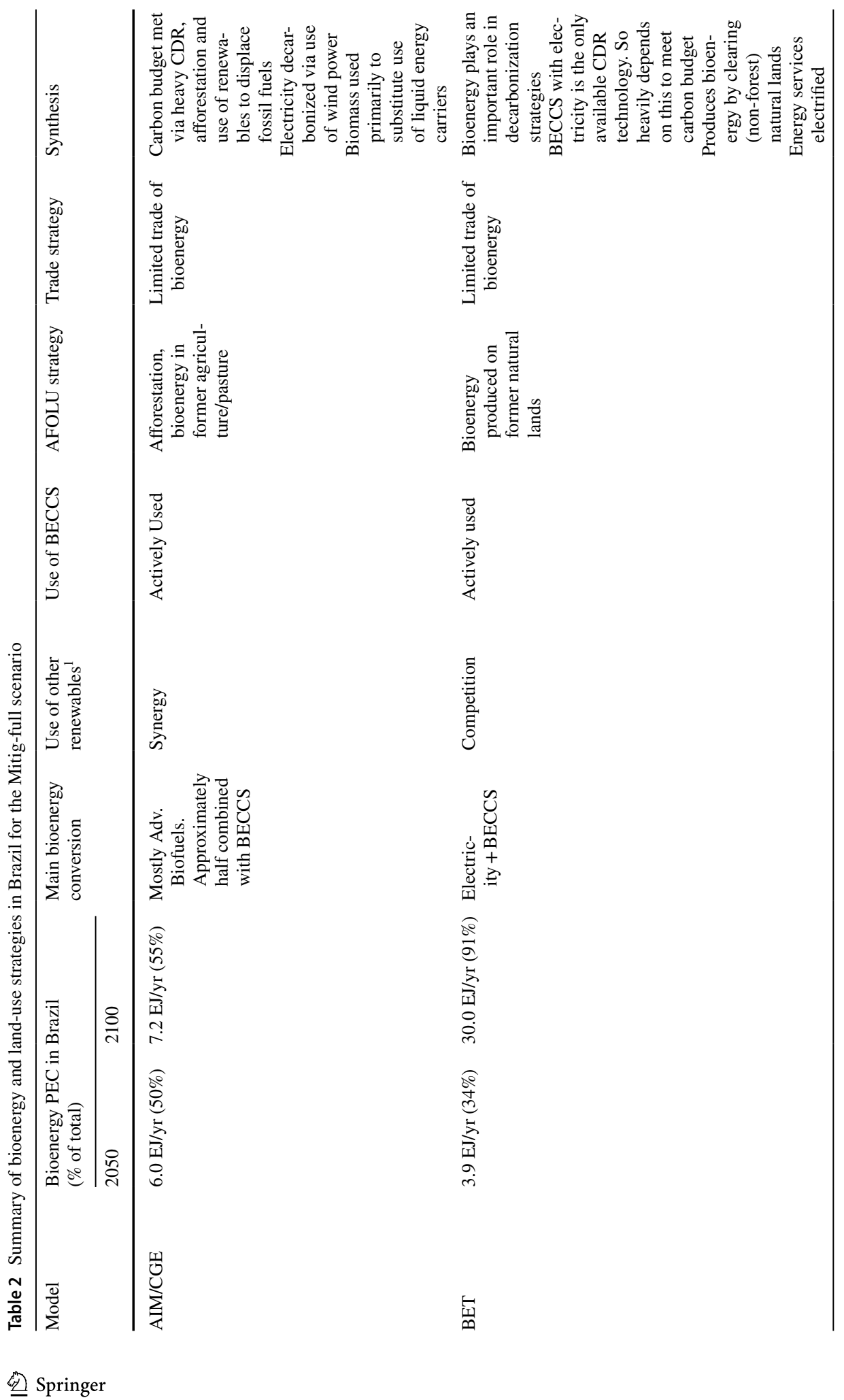


expansion, capital turnover rates, and market share constraints of individual technologies. This is also in line with the conclusions of Krey et al. (2019) and Köberle (2019) who showed the availability of alternative energy sources, feedstocks or CDR options other than BECCS in the model structures is an important determinant of its reliance on bioenergy to meet mitigation targets. As a result, it can be challenging to disentangle why models select some technologies over others without exploring the dynamics that lead to model decisions globally and at a regional level. Understanding the differences across models and unpacking what drives them is difficult with so many degrees of freedom available to the models and the variation across them. In this section, we shed some light on what causes some of these differences, focusing on bioenergy use.

\subsection{Synthesis of results}

Model strategies to meet the $\mathrm{CO}_{2}$ budget constraint are summarised in Table 2. While models project significant amounts of bioenergy to be produced in Brazil, domestic consumption depends on trade strategies, with some models opting to export their local production. The fact that IAMs solve the emission target globally may lead to differences in the distribution of regional efforts across models. Thus, individual model projections for Brazil should be placed within the global mitigation strategies each model adopts (see Sect. 4.1.3). Overall, some form of carbon sequestration is important in Brazilian energy (via BECCS, in power generation and liquids production) and land-use strategies (afforestation, agricultural intensification). Differences in carbon sequestration strategies point to different representations of land-based mitigation options and competition between land uses and cost assumptions and availability across models for the different sequestration alternatives (AFOLU, BECCS electricity, BECCS liquids, Fossil CCS). The role of nonbiomass renewable energy (NBRE) to decarbonise electricity generation can be synergistic or competitive with bioenergy in that models deploy both to decarbonise supply or one supplants the other. The foregoing has implications for the various levels of PEC, LUC and GHG emissions.

\subsubsection{Bioenergy production conversion and consumption}

Differences in PEC across models can be challenging to explain because, in the value chain, many factors are modelled endogenously with potential impact on results. Uncertainties could compound at each link. Using the bioenergy example, the resulting primary bioenergy consumption will depend on the suite of technologies in each model that convert primary biomass to secondary bioenergy carriers (ethanol, biodiesel, bioelectricity, biohydrogen, with or without CCS), and those that convert these to final energy services like mobility and heat (cars, truck, planes, boilers etc.). This final energy demand also varies across the IAMs, despite the harmonisation of exogenous drivers such as economic and population growth. The reason is that final energy is also influenced by the model methodology (recursive dynamic, equilibrium, optimisation) and endogenous feedback (learning, price responses etc.). Also, bioenergy is constrained by land availability and productivity and the costs of producing the primary bioenergy, which can be endogenously or exogenously set. Therefore, PEC in Brazil is subject to many dynamics and constraints that differ across models and cannot be explained without careful tracing of the complete bioenergy supply chain. Still, the results presented here also have some robust findings across the models. 


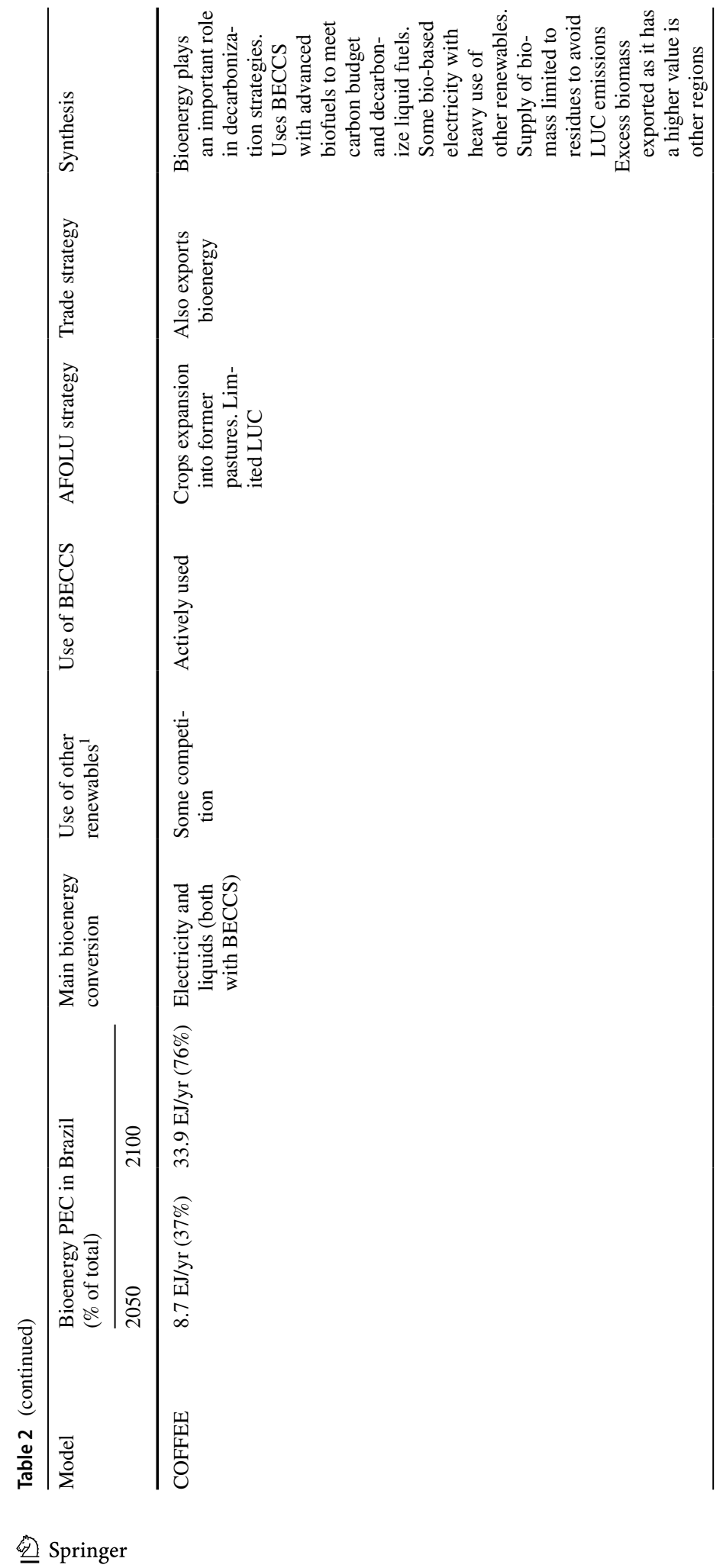




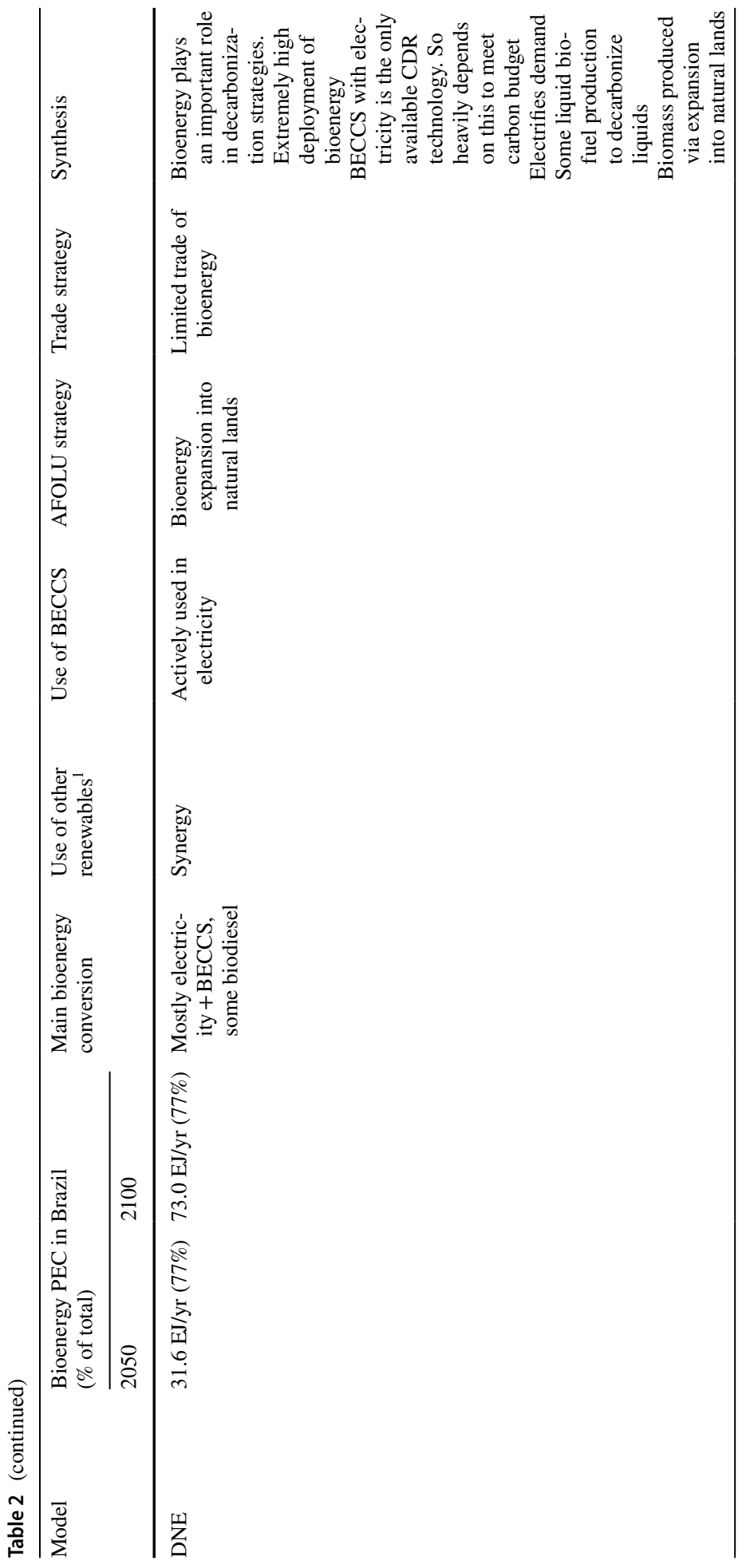




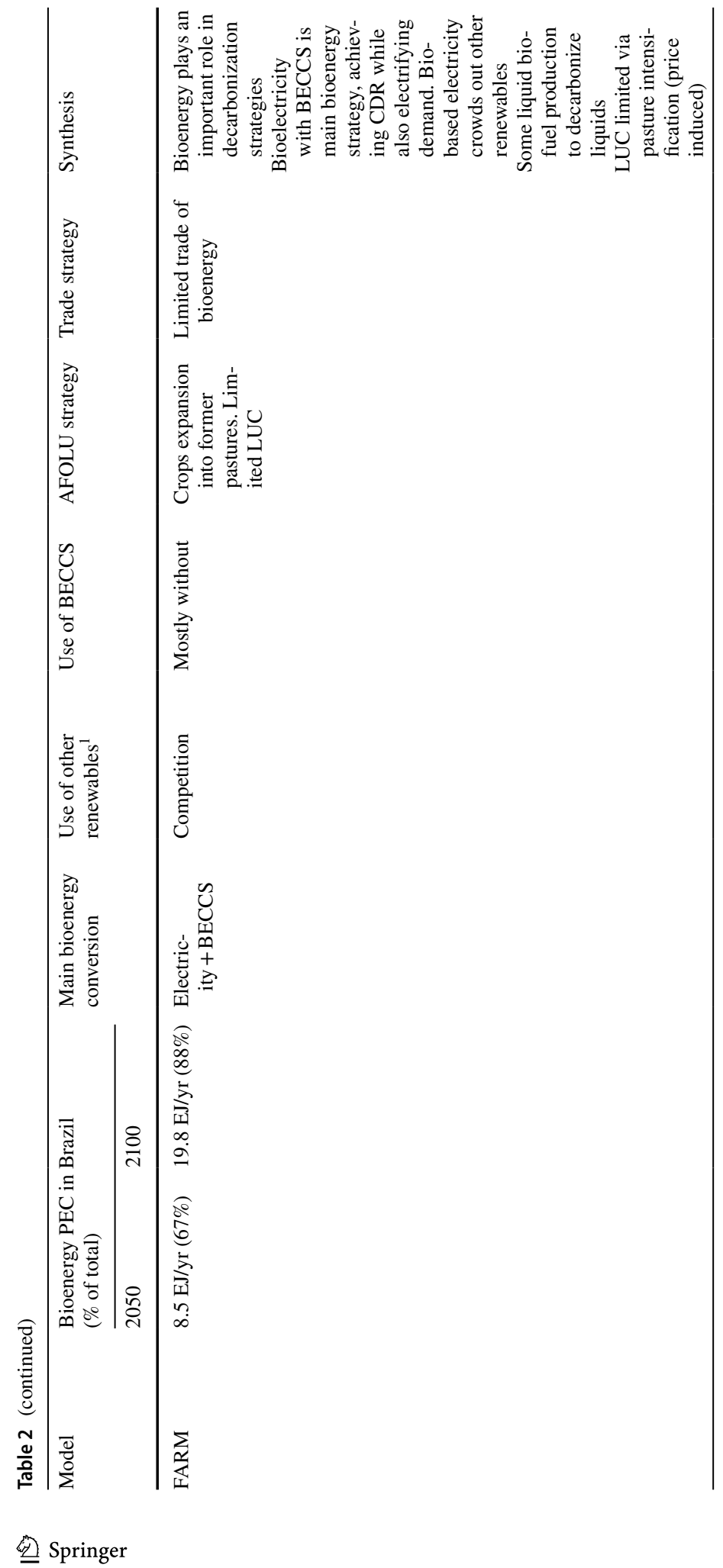




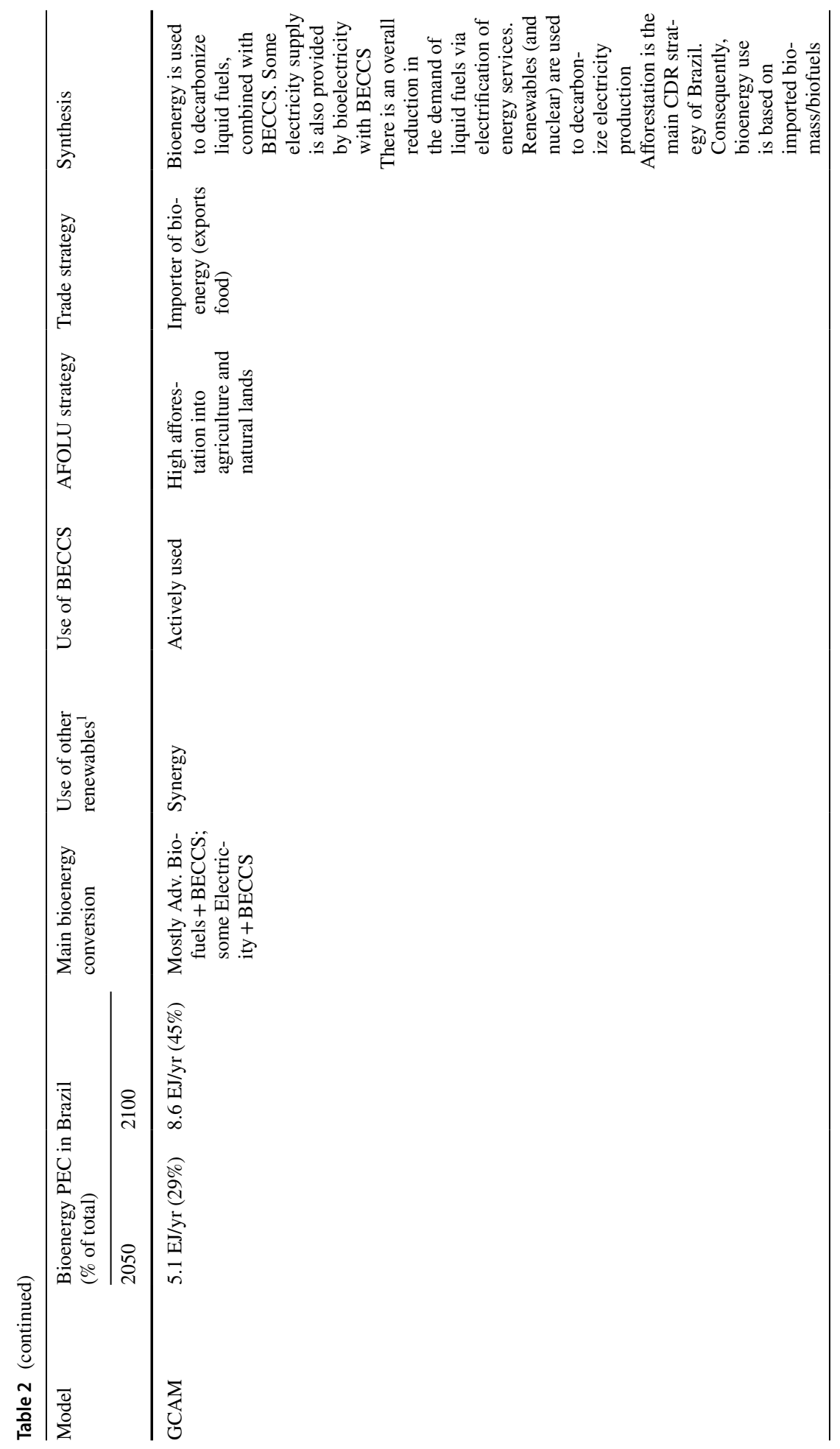




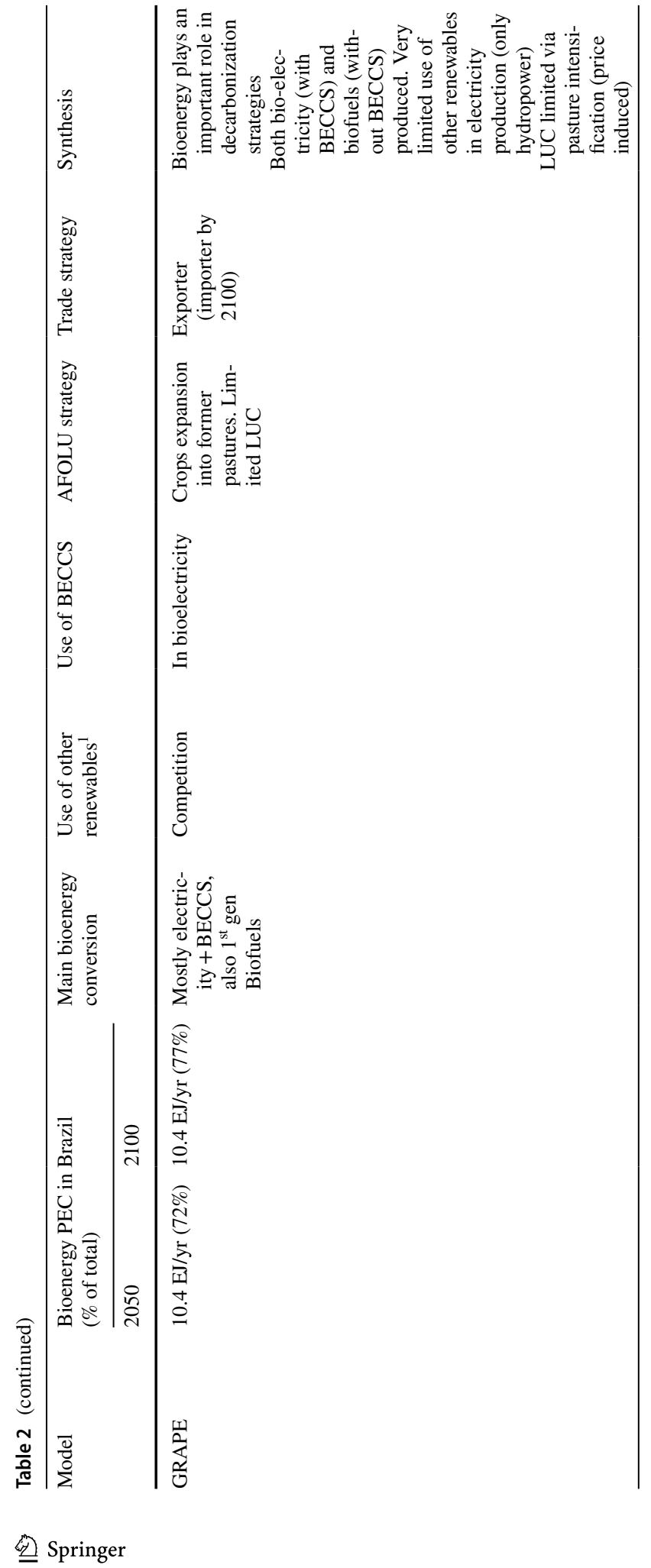




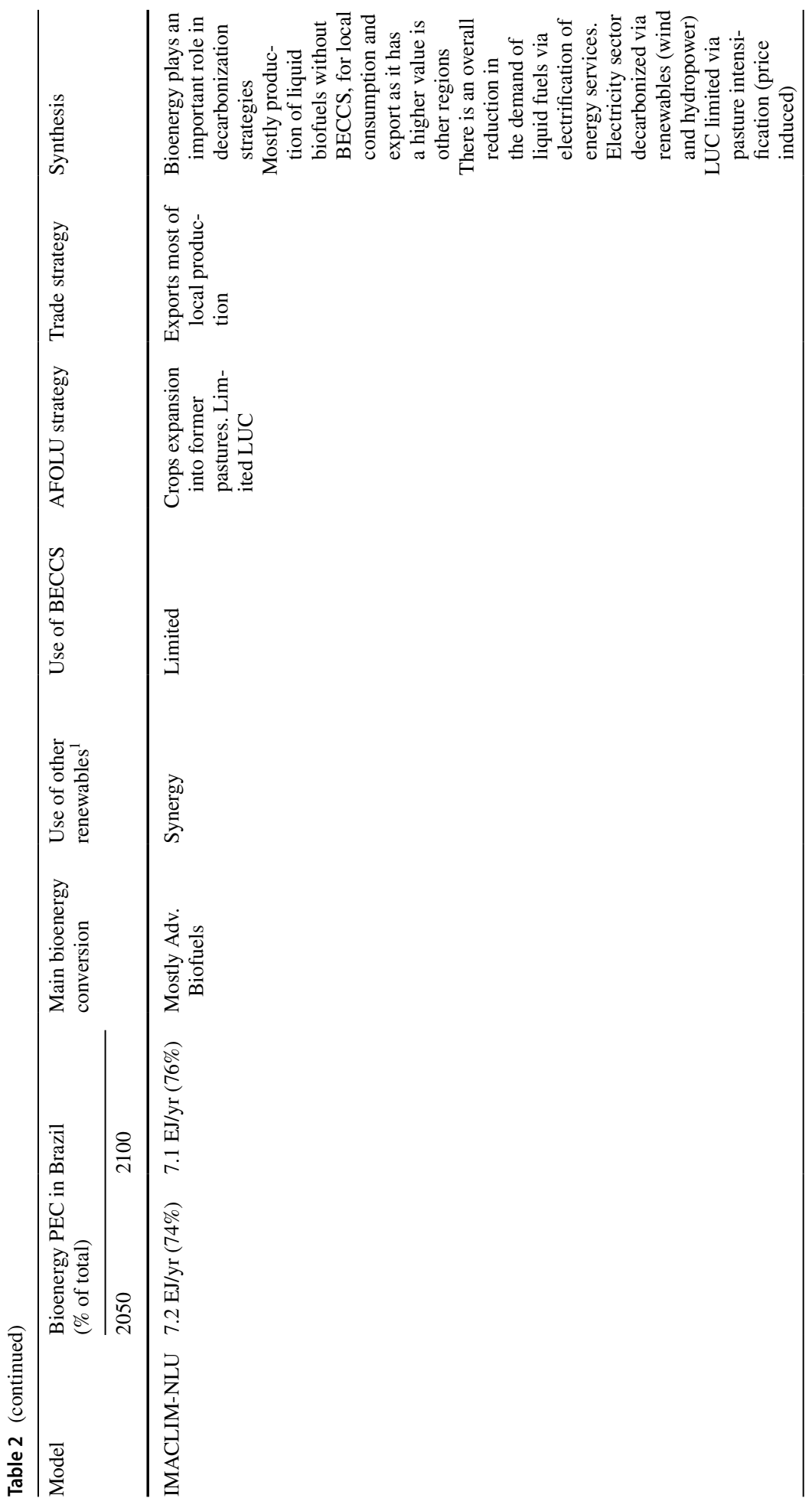




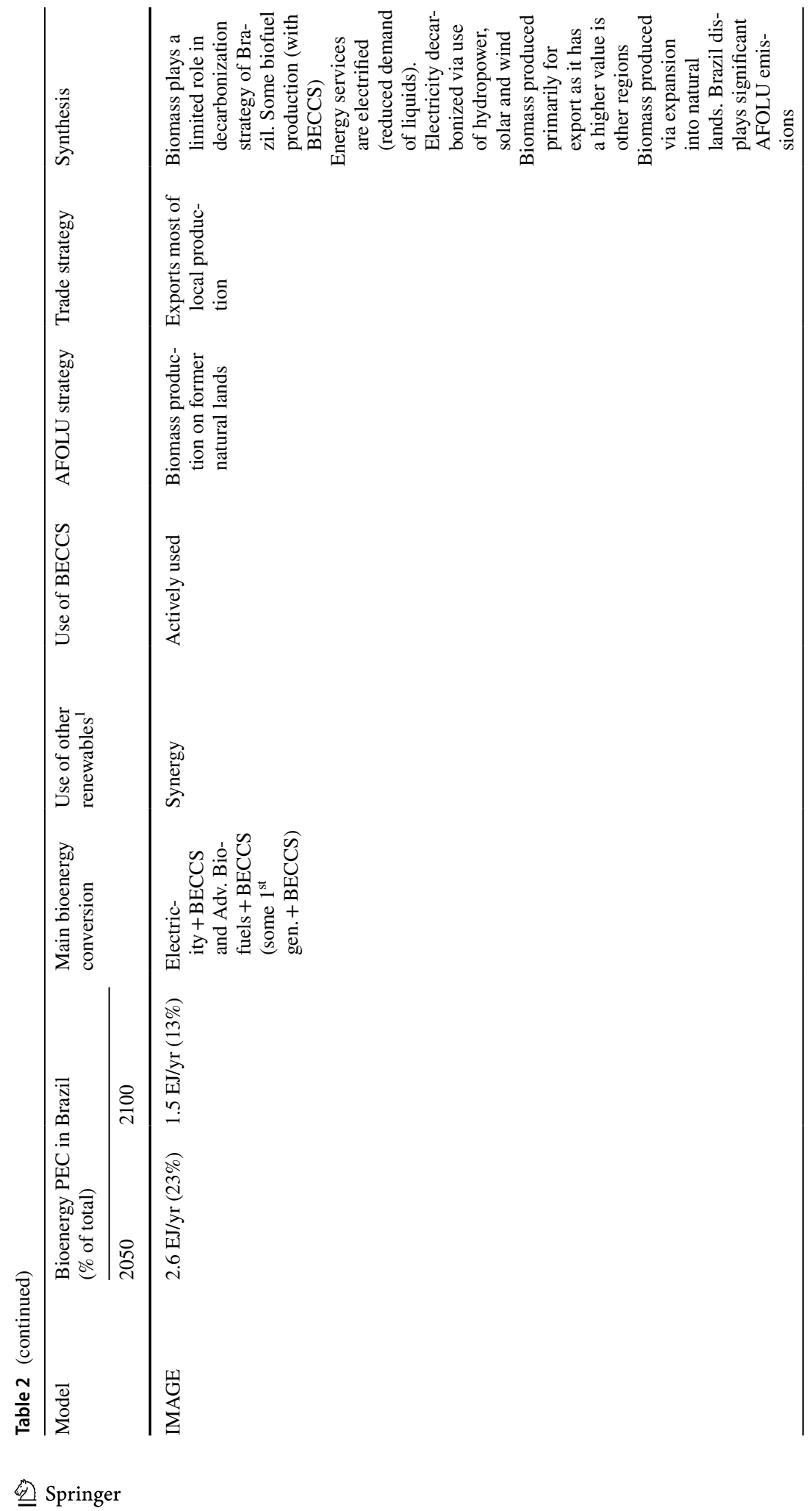




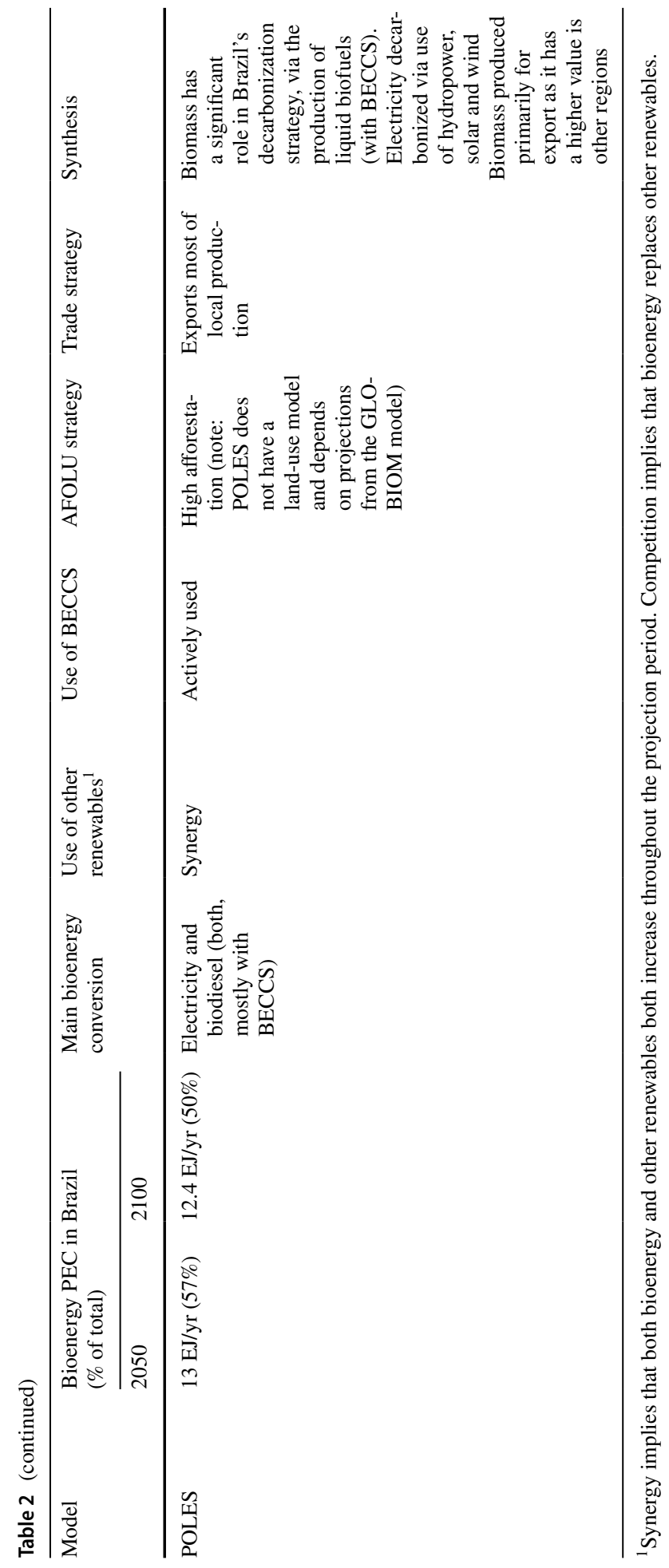


Global results from the EMF-33 scenarios show that bioenergy allocation comes down to a choice between bioelectricity and liquid biofuels (Bauer et al 2018). In mitigation scenarios, the availability of BECCS in electricity generation and liquids production helps determine the value of bioenergy vis-à-vis other low-carbon options like NBRE or nuclear. Some models (BET, DNE21 +, FARM, GRAPE) have BECCS with electricity as the only available CDR technology and tend to rely more heavily on this option to meet the carbon budget. Conversely, models with BECCS in liquids production (AIM, COFFEE, GCAM, IMAGE, POLES) tend to have a more mixed approach, using NBRE to decarbonise electricity and dedicating BECCS to decarbonise liquids. For example, IMACLIMNLU deploys bioenergy to decarbonise liquids exclusively and, because it does not have a BECCS-liquids option, it is the only model that does not deploy BECCS in any form in Brazil.

Concerning the deployment of bio-based electricity or liquid production, most models can only grow the share of an option by reducing the share of the other. Exceptions are the COFFEE model, which explicitly models sugarcane as a feedstock for ethanol and bagasse bioelectricity. Interestingly, IMACLIM-NLU adopts a bioliquids strategy despite not having CCS available in their production as feedstock is made available by the full decarbonisation of power generation via NBRE alternatives (Fig. 1b). For Brazil, this is not impossible as already over $70 \%$ of the electricity comes from renewables (mostly hydro, see Section S1). Finally, the choice to deploy more liquid biofuels also depends on the availability of alternative low-carbon electricity generation options like wind and solar and the extent to which the models include grid integration constraints on their penetration (Daioglou, et al. 2020a, b; Köberle 2019).

\subsubsection{Land use dynamics}

The large disparity in land-use strategies projected by the models arises from how the models deal with land-use competition and intensification, the possibility for afforestation, and projections of food demand and productivity. Representation of land use dynamics across models follow various methods, with associated shortcomings. IMACLIM-NLU and FARM have limited endogenous land use change representation whereby natural forest area is exogenously determined in both and held fixed in EMF-33 scenarios. ${ }^{5}$ This drives up the cost of bioenergy by putting it in direct competition with food production for land. COFFEE and POLES do not have links to spatially explicit gridded land use models, and therefore rely on regional average parameters for land use such as exogenous emission factors, production costs, land productivity. COFFEE models energy and land use together under the same objective function, while POLES uses soft links to scenarios produced by the GLOBIOM agriculture and land use model. ${ }^{6}$ The IMAGE model has a "food-first" paradigm, where bioenergy potential is determined after determining land required to meet food production needs, and bioenergy is not allowed to lead to deforestation. For an overview of the modelling of bioenergy feedstock supply in EMF-33, see (Rose et al. 2021).

Most models show continued loss of natural lands (deforestation) to make room for cultivated areas for crop and livestock. All models display increasing yields of bioenergy and food crops across all scenarios, with compounded annual growth rates (CAGRs) well

\footnotetext{
5 This assumption is not realistic for Brazil (Rochedo et al. 2018) or other tropical countries where unmanaged tropical forests are especially at great risk around the world (Hansen et al., 2013), suggesting potential avenues for model improvement.

${ }^{6}$ https://iiasa.ac.at/web/home/research/GLOBIOM/GLOBIOM.html
} 
above $1 \%$ per year in some cases, with these yield improvements making room for production of food or bioenergy, or for afforestation. AIM/CGE, GCAM, and POLES rely more on afforestation and its use as a CDR measure than other models, driven both by low cost assumptions for afforestation and the high carbon stock and productivity of Brazilian forests. For example, GCAM deploys the afforestation potential in the near-term, made possible by assumptions of flexible trade and land use dynamics. Partly due to scenario design assumptions, GCAM projects a 90\% reduction in crop production and cropland from 2010 to 2030, an unrealistic outcome in a country where agricultural production is such a large contributor to GDP (see Section S10).

Livestock intensification has been recognised as a way to make land available for both food and bioenergy crops both globally (Cohn et al. 2014; Havlik et al. 2014; Herrero et al. 2010) and in Brazil (Assad et al. 2015; Köberle et al. 2015, 2020; Strassburg et al. 2014). As noted in Sect. 3, most models show pasture area declining in Brazil across scenarios driven by increasingly productive livestock systems. IMACLIM-NLU is an example of a model that explicitly represents livestock intensification which the model deploys in Brazil in the baseline to its full potential (Leblanc et al., this issue), which is how the model creates space for bioenergy production since it is not allowed to expand agriculture onto natural lands. However, not all models represent intensification endogenously. Although IMAGE shows an increase in pasture area, this is due to cost competitiveness of the Brazilian livestock sector, causing projected gains from intensification to be converted to higher production for export.

\subsubsection{Global context}

The results shown in this manuscript are based on modelled scenarios where global carbon budgets are met. Thus, the projections for Brazil should be understood within their global context, and the actions of other regions. This has important implications when interpreting the energy, land-use, international trade, and resultant regional GHG profiles. As explained above, the differences across model global and regional mitigation strategies depend upon the complex interactions between the modelled availability and relative costs of different mitigation options (including bioenergy, other renewables, and efficiency improvement), constraints on the speed of energy system transition, and the relative demand of different energy services (see table S1, and Daioglou et al. (2020a, b)).

The EMF-33 project has highlighted that bioenergy trade dynamics are an important determinant of primary bioenergy consumption and production in different model regions (Daioglou et al. 2020a, b). Some models leverage the high potential for NBRE in Brazil allowing them to exploit the country's bioenergy potential to export surplus primary and/or secondary bioenergy as it has higher value in other regions. COFFEE and GRAPE export any surplus biomass, while in IMACLIM-NLU, IMAGE and POLES biomass is produced primarily for export. Conversely, in GCAM Brazil features as a food exporter (livestock products mainly, See Section S10), with afforestation as its main CDR strategy and, consequently, its bioenergy is imported. DNE21+exports small amounts of liquid biofuels and hydrogen produced from bioelectricity, but no primary biomass trade is allowed in the model. Other models have limited biomass trade. Therefore, different trade strategies resulting from assumptions and the representation of trade relations, as well as regional 
mitigation costs, determine how specific regions feature within global results. Interestingly, trade strategies for Brazil may preclude net negative emissions since any land productivity gains in the country can be absorbed by bioenergy production for export, as for example in IMAGE.

Figure S5 shows projections of Brazilian and Global $\mathrm{CO}_{2}$ emissions for the MitigFull scenario, disaggregated across the Energy and AFOLU sectors, as well as the total emissions (Energy + AFOLU). As shown, a plethora of emission strategies for Brazil are selected across models. The first split across model strategies concerns the role of Brazil in global carbon budgets. As shown, BET, COFFEE, DNE21+, and POLES project Brazil to be a major provider of CDR, supplying $>10 \%$ of the required global net negative emissions by 2100 . GCAM also does this early on via the AFOLU sector with aggressive afforestation. Another set of models (AIM/CGE, FARM, GRAPE, IMACLIM-NLU, and IMAGE) depend less on net negative emissions, and so Brazil also plays a less important role here.

The second split concerns the relative importance of the AFOLU and Energy sectors in the mitigation (and CDR) of Brazilian emissions. For BET, COFFEE, DNE21 +, GRAPE, and to a lesser extent IMAGE and FARM, the energy system is the primary purveyor of emission mitigation and net negative emissions. These are models which project a significant amount of BECCS. Other models show little or no negative emissions, explained by a reliance on NBRE technologies to decarbonise power generation and the absence of BECCS-liquids options (FARM, IMACLIM-NLU). On the other hand, AIM/CGE, GCAM and POLES show the AFOLU sector to provide most of the emission mitigation for Brazil, via afforestation and agricultural intensification.

\subsection{Comparing to current trends}

Brazil is currently one of the largest producers of bioenergy, mostly first-generation biofuels (from soy and sugarcane) and bioelectricity (from sugarcane bagasse). Today, the most important energy crop in Brazil is sugarcane for the production of not only sugar and ethanol, but also steam and electricity from combustion of bagasse in Rankine cycle thermal power plant. The very diverse bioenergy feedstock mix going to virtually all sectors of the Brazilian economy is very particular to Brazil and is not well represented in model structures. Instead, most models follow a global template of energy supply and demand with a uniform mix of technologies available in all regions of each model. This template varies across models but not across regions in a single model.

An issue that stands out is the underrepresentation of first-generation biofuels, since many IAMs downplay first-generation biofuels because advanced biofuels are projected to be more competitive in the medium term (Bauer et al. 2018; Daioglou, et al. 2020a, b; Rose et al. 2021). Although the EMF-33 scenario protocol focused on advanced bioenergy technology (second-generation, usually combined with CCS), model representation of first-generation bioenergy is not in line with current or potential uses in Brazil. For example, first-generation sugarcane ethanol is by far the most important biofuel in Brazil today and likely to remain so for the foreseeable future (Köberle et al. 2020). In the case of biodiesel, the $20 \%$ share of beef tallow in the feedstock (ANP 2017) is something that is not included as an option in any of the models included here.

Even second-generation biofuel routes tend to be underrepresented, and those advanced biofuel routes that are included tend to be the same across models. For instance, most IAMs do not explicitly model second-generation biofuels from sugarcane bagasse, which is expected to be an important biofuel production route with a pilot plant already in operation 
in Brazil. ${ }^{7}$ Moreover, ethanol itself can be converted to jetfuel or diesel for example via an alcohol-to-jet (ATJ) route (de Jong et al. 2015) that is not present in most models (except COFFEE) but which is identified by the Brazilian model BLUES as a viable option (Köberle et al. 2020). All this suggests that capturing the specificities of bioenergy consumption in Brazil is something most IAMs cannot do reliably.

On negative emissions technologies (NETs), detailed techno-economic analysis have shown BECCS-liquids to have high potential in decarbonising Brazil's transportation system as well as for exports of low-carbon liquid fuels, with emphasis on advanced biofuels from sugarcane products (Köberle et al. 2020; Tagomori et al. 2019). Although there is plenty of carbon storage potential in Brazil, there are no CCS pilot projects currently in place and, as is the case globally, governance issues will need to be resolved before major $\mathrm{CO}_{2}$ storage can take place. However, should CCS become a viable option in the future, model results suggest Brazil could become an important carbon sink.

Achieving the low land-use change emissions and CDR projected by the models would require reversal of current trends of deforestation which, although much reduced from peak 2004-2005 levels in the Amazon (INPE 2017; MCTIC 2016; Nepstad et al. 2009; SEEG 2019), is still far from zero and has grown recently from the minimum level of $4,571 \mathrm{~km}^{2}$ in 2012 (Brasil 2017a; INPE 2017; Soares-filho et al. 2014; Rochedo et al. 2018). Deforestation in the other Brazilian biomes, especially in the Cerrado biome, ${ }^{8}$ is also still high (Brasil 2017a, 2017b; Rochedo et al. 2018). As a result, LULUCF accounted for about 65\% of Brazil's $\mathrm{CO}_{2}$ emissions in 2019, down from its $80 \%$ peak in 2005, but still adding up to $74 \%$ of cumulative $\mathrm{CO}_{2}$ emissions since 1990 (SEEG 2019). Recent political reversals have undermined policies that sustain the continued reductions in deforestation, which has risen again since 2012 (Amigo 2020; Lovejoy \& Nobre 2019; Rochedo et al. 2018). As for the future, there is no official target to end deforestation in the country, although the Brazilian NDC has a target to end illegal deforestation by 2030 (GofB 2015). However, recent political rhetoric has undermined environmental legislation, and forest protection has become a bargaining chip (Rochedo et al. 2018).

On the other hand, yield improvements can potentially reduce the land use change tradeoffs by reducing pressures on forested areas and even sparing land for afforestation. This applies particularly to a vast, inefficiently used pasture area with high potential for landsparing through intensification that could provide space for bioenergy production growth (Assad et al. 2015; Köberle et al. 2015; Köberle et al. 2020; Strassburg et al. 2014). Pastureland intensification is here defined as improvement of pasture management to increase productivity ( $\mathrm{kg}$ of product per hectare per year) and stocking rates (animals per hectare) in such a way that they approach the biophysical potential of Brazilian pastures in the various biomes and locations in the country. This usually involves higher use of inputs such as diesel, fertilisers and lime but produces significant gains in productivity with potential net reductions in GHG emissions (Cardoso et al. 2016). Although intensification potential as a mitigation option is debatable (Smith 2013), the low efficiency of current livestock systems in Brazil opens the door for mitigation through efficiency improvements that decouple the activity from deforestation (De Oliveira Silva et al. 2016; Silva et al. 2017; Strassburg et al. 2014).

Agricultural intensification raises the opportunity costs of conservation since higher yields imply possible higher profits depending on the elasticity of demand (Byerlee et al.

\footnotetext{
${ }^{7}$ In 2020 there is one pilot lignocellulosic facility converting bagasse to ethanol (via hydrolysis). http://www.iogen.ca/raizen-project/

${ }^{8}$ Vast highland savannas in central Brazil.
} 
2014) and greater incentives to convert land (Nepstad et al. 2009; Rose et al. 2013) and, because this aspect is not captured in IAMs, the land-sparing potential of intensification may be overestimated. Moreover, there is need for sustained investment if agricultural yields are to reach the levels implied by the model results in this study, and this is true for all crops, including energy crops. In addition, it would most likely mean implementation of current best practices from the most productive regions in those lagging behind. One outcome of climate policies in Brazil could be the reversal of the downward trend in sugarcane yield via a return of investments, spurred by the higher value of the crop as a low-carbon feedstock.

\section{Conclusions}

The EMF-33 project has highlighted that, at a global level, IAMs agree on the importance of biomass and bioenergy as a climate change mitigation measure (Bauer et al. 2018). This study focuses on the projections for a specific region, Brazil, and presents and assesses the projections of this region across global models. By doing this, we aim to identify potential robust bioenergy futures for Brazil and identify and assess variation in results across models.

Modelled bioenergy strategies for Brazil vary across models. While this indicates the plethora of possible regional strategies, it also limits the usefulness of global scenarios from global IAMs for local policymaking. In the results presented, differences in regional strategies arise from differences in the structure of different IAMs (particularly how they deal with land use and AFOLU emissions) and scenario design, as these impact model parameterisation, the resulting global energy and land-use strategies, and the narratives which guide these strategies. Those models that lack a BECCS option in liquid biofuels production and an afforestation land strategy (BET, DNE21 +, FARM, GRAPE) show lower use of liquid biofuels and provide high levels of carbon dioxide removal by deploying large scale use of biomass to produce electricity combined with CCS. Other models follow bioenergy strategies based on liquid biofuels, with other renewables decarbonising the electricity sector (AIM/CGE, GCAM, IMACLIM-NLU). A third set of models shows a mixed deployment of these technologies, always combined with BECCS (COFFEE, IMAGE, POLES).

While the model comparison presented does not offer robust projections of bioenergy use in Brazil, all models agree on the importance of this region's AFOLU sector.

This could either be via increased afforestation to provide high CDR levels consistent with $2{ }^{\circ} \mathrm{C}$ scenarios (AIM/CGE, GCAM) or via bioenergy production to decarbonise the energy system (local or for export) and provision of CDR via BECCS. In all cases, bioenergy plays a significant role in the Brazilian energy system by 2050 (23-77\% of PEC), and the intensification of agriculture and pastures is of particular importance in all modelled pathways. 
Model projections of Brazil cannot be viewed independently of the global context The results shown in this manuscript are based on modelled scenarios where global carbon budgets are met. Thus, the projections for Brazil should be understood within the global context and the actions of other regions. Bioenergy and land-use projections of Brazil are potentially pivotal in this context providing significant greenhouse gas mitigation capacity either by local afforestation and the use of BECCS or by producing low (or negative) emission fuels exported to other regions. Specifically, the IMAGE, IMACLIM-NLU and POLES models project Brazil to export most of its bioenergy production to regions where it has a higher decarbonisation value. The potential importance of Brazil in global carbon budgets is further highlighted by the fact that some models (BET, COFFEE, DNE21+, POLES, and GCAM in the short-medium term) project Brazil to be a significant provider of CDR, supplying $>10 \%$ of the required global net negative emissions by 2100 by either BECCS or Afforestation. Models with sticky assumptions about regional production and trade have regional results more in line with history but may be overly constrained in their ability to reflect future changes. Models with more open trade assumptions (e.g. GCAM) can respond more easily to carbon prices and may produce results that depart from history (radically in some cases), indicating the economic pressures that come from mitigation policy.

\section{In their default structure, global IAMs have aggregated agricultural and land-use strategies, bioenergy feedstocks, and conversion technologies, which may limit their} appropriateness for regional assessments. This is highlighted by the fact that the current diverse bioenergy feedstock mix going to virtually all sectors of the Brazilian economy is not well represented in most IAMs. Instead, they follow a global template of energy supply and demand with a uniform mix of technologies in all regions of each model, varying across models but not across regions in a single model. This simplification could lead to IAMs downplaying 1st generation biofuels (Bauer et al 2018; Daioglou et al 2020a, b), while sugarcane ethanol is by far the most important biofuel in Brazil today. Furthermore, IAMs tend to aggregate technologies and dynamics which determine agricultural intensification and land-use change, particularly livestock intensification and economic and political drivers of land-use change. These simplifications, in turn, affect projected bioenergy potentials, prices, and competitiveness. The supply, cost, and effectiveness of bioenergy as a climate change mitigation measure depend a lot on the location of production, local environmental, technological, feedstock, energy system specificities, and logistical constraints (Cintas et al. 2021; Daioglou et al. 2017; Donnison et al. 2020; Hanssen et al. 2020a, b; Langholtz et al. 2020).

In their default form, global scenarios from global IAMs produce results that may not be literally useful for national or regional analysis by simply extracting output variables for the region of interest.

At a minimum, sub-global results require interpreting in the context of the global modelling and the scenario specifications themselves need to be interrogated. Ideally, subglobal analyses should include some level of model development that focuses on a region of interest in the scenario and data construction while running that region within the global model. In fact, global models can provide broad trend lines for national trajectories and can provide boundary conditions for national models, e.g. for globally determined variables like international trade of energy and agricultural products. This suggests fertile ground for a new research agenda to improve regional representation in global IAMs with improved spatial and technological resolutions. A productive starting point would be to link global 
and regional models as this would account for both the global aspects of mitigation pathways (carbon budgets, international trade) and regional characteristics that affect resource potentials, logistics, and dispatch. Improving regional differentiation of technologies and land-use dynamics should be a priority research agenda for IAMs.

Supplementary Information The online version contains supplementary material available at https://doi. org/10.1007/s 10584-021-03236-4.

Funding ACK received support from the Brazilian Conselho Nacional de Desenvolvimento Cientifico e Tecnologico (CNPq). Award number: bolsa de doutorado.

Conselho Nacional de Desenvolvimento Científico e Tecnológico,Bolsa de doutorado,Alexandre C Köberle. S.F is supported by the Environment Research and Technology Development Fund (JPMEERF20211001) of the Environmental Restoration and Conservation Agency of Japan.

Data availability Data is available upon reasonable request from lead author.

Code availability Code was written only to build figures. For code and structure to the underlying models, the reader is referred to the model documentations. Links to individual models can be found at https://www. iamcdocumentation.eu/index.php/IAMC_wiki.

\section{Declarations}

Conflict of interest The authors declare no competing interests.

Open Access This article is licensed under a Creative Commons Attribution 4.0 International License, which permits use, sharing, adaptation, distribution and reproduction in any medium or format, as long as you give appropriate credit to the original author(s) and the source, provide a link to the Creative Commons licence, and indicate if changes were made. The images or other third party material in this article are included in the article's Creative Commons licence, unless indicated otherwise in a credit line to the material. If material is not included in the article's Creative Commons licence and your intended use is not permitted by statutory regulation or exceeds the permitted use, you will need to obtain permission directly from the copyright holder. To view a copy of this licence, visit http://creativecommons.org/licenses/by/4.0/.

\section{References}

Alexandratos N, Bruinsma J (2012) WORLD AGRICULTURE TOWARDS 2030 / 2050 The 2012 Revision. In Food and Agriculture Organization of the United Nations (Issue 12). https://doi.org/10.1016/ S0264-8377(03)00047-4

Amigo I (2020) When will the Amazon hit a tipping point? Nature. https://doi.org/10.1038/ d41586-020-00508-4

ANP (2017) Boletim Mensal do Biodiesel - Fevereiro 2017: Vol. d. https://www.gov.br/anp/pt-br/assun tos/producao-e-fornecimento-debiocombustiveis/biodiesel/if/bmb/2017/boletim-biodiesel-02.pdf. Accessed 27 Dec 2021.

ANP (2018) Percentual obrigatório de biodiesel passa para 10\%. Associacao Nacional Do Petroleo e Biocombustiveis (ANP) Website.https://www.gov.br/anp/pt-br/canais_atendimento/imprensa/noticiascomunicados/percentual-obrigatorio-de-biodiesel-passa-para-10. Accessed 27 Dec 2021.

ANP (2021) Mistura de biodiesel ao diesel passa a ser de 13\% a partir de hoje. Associacao Nacional Do Petroleo e Biocombustiveis (ANP) Website. https://www.gov.br/anp/pt-br/canais_atendimento/impre nsa/noticias-comunicados/mistura-de-biodiesel-ao-diesel-passa-a-ser-de-13-apartir-de-hoje-1-3. Accessed 27 Dec 2021.

Assad E, Pavão E, de Jesus M, Martins SC (2015) Invertendo o sinal de carbono da agropecuária brasileira. Uma estimativa do potencial de mitigação de tecnologias do Plano ABC de 2012 a 2023. http://www. observatorioabc.com.br/relatorio-5-invertendo-o-sinal-de-carbono-da-agropecuaria-brasileira?locale= pt-br 
Assunção J, Pietracci B, Souza P (2016) Fueling Development: Sugarcane Expansion Impacts in Brazil. https://www.inputbrasil.org/wp-content/uploads/2016/07/Fueling_Development_Sugarcane_Expan sion_Impacts_in_Brazil_Working_Paper_CPI.pdf.pdf. Accessed 27 Dec 2021.

Bauer N, Rose SK, Fujimori S, Van Vuuren D, Weyant J, Wise M, Cui Y, Daioglou V, Gidden MJ, Kato E, Kitous A, Leblanc F, Sands RD, Sano F, Strefler J, Tsutsui J, Bibas R, Fricko O, Hasegawa T, ... Muratori M (2018) Global energy sector emission reductions and bioenergy use: overview of the bioenergy demand phase of the EMF-33 model comparison. Clim Change. https://doi.org/10.1007/ s10584-018-2226-y

Biggs R, Raudsepp-Hearne C, Atkinson-Palombo C, Bohensky E, Boyd E, Cundill G, Fox H, Ingram S, Kok K, Spehar S, Tengö M, Timmer D, Zurek M (2007) Linking futures across scales: a dialog on multiscale scenarios. Ecol Soc 12(1). https://doi.org/10.5751/ES-02051-120117

Brasil (2017a) Meta de Redução do desmatamento no cerrado. Os planos de Prevencao e Controle do desmatamento em ambito federal. http://combateaodesmatamento.mma.gov.br/. Accessed 27 Dec 2021.

Brasil (2017b) Planos de ação para a prevenção e o controle do desmatamento. http://combateaodesmat amento.mma.gov.br/images/conteudo/Planos_ultima_fase.pdf

Byerlee D, Stevenson J, Villoria N (2014) Does intensification slow crop land expansion or encourage deforestation? Glob Food Sec 3(2):92-98. https://doi.org/10.1016/j.gfs.2014.04.001

Cardoso AS, Berndt A, Leytem A, Alves BJR, de Carvalho I. das NO, de Barros Soares LH, Urquiaga S, Boddey RM (2016) Impact of the intensification of beef production in Brazil on greenhouse gas emissions and land use. Agric Syst 143, 86-96. https://doi.org/10.1016/j.agsy.2015.12.007

Carvalho F, Portugal-pereira J, Koberle A, Szklo A (2016) Biojet fule in Brazil: technological routes and feedstock availability. Proceedings of the 24th European Biomass Conference \& Exhibition. http:// www.etaflorence.it/proceedings/

Cintas O, Berndes G, Englund O, Johnsson F (2021) Biomass and Bioenergy Geospatial supply-demand modeling of lignocellulosic biomass for electricity and biofuels in the European Union. Biom Bioenerg 144(November 2020). https://doi.org/10.1016/j.biombioe.2020.105870

Cohn AS, Mosnier A, Havlík P, Valin H, Herrero M, Schmid E, O’Hare M, Obersteiner M (2014) Cattle ranching intensification in Brazil can reduce global greenhouse gas emissions by sparing land from deforestation. Proc Natl Acad Sci USA 111(20):7236-7241. https://doi.org/10.1073/pnas.1307163111

Conab (2017) Séries Históricas de Área Plantada, Produtividade e Produção, Relativas às Safras 1976/77 a 2015/16 de Grãos, 2001 a 2016 de Café, 2005/06 a 2016/17 de Cana-de-Açúcar. Séries Históricas. http://www.conab.gov.br/conteudos.php?a=1252\&Pagina_objcmsconteudos=2\#A_objcmsconteudos

Creutzig F, Ravindranath NH, Berndes G, Bolwig S, Bright R, Cherubini F, Chum H, Corbera E, Delucchi M, Faaij A, Fargione J, Haberl H, Heath G, Lucon O, Plevin R, Popp A, Robledo-Abad C, Rose S, Smith P, ... Masera O (2015) Bioenergy and climate change mitigation: an assessment. GCB Bioenergy 7(5) 916-944. https://doi.org/10.1111/gcbb.12205

Daioglou V, Doelman JC, Stehfest E, Müller C, Wicke B, Faaij A, van Vuuren DP (2017) Greenhouse gas emission curves for advanced biofuel supply chains. Nat Clim Chang 7(12):920-924. https://doi.org/ 10.1038/s41558-017-0006-8

Daioglou V, Muratori M, Lamers P, Fujimori S, Kitous A, Köberle AC, Bauer N, Junginger M, Kato E, Leblanc F, Mima S, Wise M, van Vuuren DP (2020a) Implications of climate change mitigation strategies on international bioenergy trade. Clim Change 163(3):1639-1658. https://doi.org/10.1007/ s10584-020-02877-1

Daioglou V, Rose S, Bauer N, Kitous A, Muratori M, Sano F, Fujimori S, Gidden MJ, Kato E, Keramidas K, Klein D, Leblanc F, Tsutsui J, Wise M, van Vuuren DP (2020b) Bioenergy technologies in long-run climate change mitigation: results from the EMF33 study. Clim Change 163:1603-1620

de Jong S, Hoefnagels R, Faaij A, Slade R, Mawhood R, Junginger M (2015) The feasibility of short term production strategies for renewable jet fuels - a comprehensive techno-economic comparison. Biofuels Bioprod Biorefin 9:778-800. https://doi.org/10.1002/bbb.1613;Biofuel,Bioprod.Bioref.9: 778-800(2015)

De Oliveira Silva R, Barioni LG, Hall JAJ, Folegatti Matsuura M, Zanett Albertini T, Fernandes FA, Moran D (2016) Increasing beef production could lower greenhouse gas emissions in Brazil if decoupled from deforestation. Nat Clim Chang 6(5):493-497. https://doi.org/10.1038/nclimate2916

Dellink R, Chateau J, Lanzi E, Magné B (2015) Long-term economic growth projections in the Shared Socioeconomic Pathways. Global Environmental Change, IN PRESS, 1-15. https://doi.org/10.1016/j. gloenvcha.2015.06.004

Donnison C, Holland RA, Hastings A, Felix LA, Gail E (2020) Bioenergy with Carbon Capture and Storage (BECCS): Finding the win - wins for energy, negative emissions and ecosystem services - size matters. GCB Bioenergy March, 586-604. https://doi.org/10.1111/gcbb.12695 
EPE (2015) PNE - Cenário econômico 2050. http://www.epe.gov.br/pt/publicacoes-dados-abertos/publi cacoes/Plano-Nacional-de-Energia-2050. Accessed 27 Dec 2021.

EPE (2019) Balanço Energético Nacional. https://epe.gov.br/pt/publicacoes-dados-abertos/publicacoes/ balanco-energetico-nacional-2019

EPE (2020) Análise de conjuntura dos biocombustíveis - Ano 2019. https://www.epe.gov.br/sites-pt/publi cacoes-dados-abertos/publicacoes/PublicacoesArquivos/publicacao-489/Analise_de_Conjuntura_ Ano_2019.pdf

FIESP (2015) Outlook Fiesp 2025: projeções para o agronegócio brasileiro. http://hotsite.fiesp.com.br/outlo okbrasil/2025/files/assets/common/downloads/publication.pdf. Accessed 27 Dec 2021.

Fricko O, Havlik P, Rogelj J, Klimont Z, Gusti M, Johnson N, Kolp P, Strubegger M, Valin H, Amann M, Ermolieva T, Forsell N, Herrero M, Heyes C, Kindermann G, Krey V, McCollum DL, Obersteiner M, Pachauri S, ... Riahi K (2016) The marker quantification of the Shared Socioeconomic Pathway 2: a middle-of-the-road scenario for the 21 st century. Glob Environ Chang. https://doi.org/10.1016/j.gloen vcha.2016.06.004

Gasparatos A, Stromberg P, Takeuchi K (2011) Biofuels, ecosystem services and human wellbeing: putting biofuels in the ecosystem services narrative. Agr Ecosyst Environ 142(3-4):111-128. https://doi.org/ 10.1016/j.agee.2011.04.020

GofB (2015) Intended Nationally Determined Contribution (INDC) towards achieving the objective of the UNFCCC. https://www4.unfecc.int/sites/submissions/INDC/Published\%20Documents/Brazil/1/BRAZIL\%20iNDC\%20english\%20FINAL.pdf. Accessed 27 Dec 2021.

Goldemberg J, Coelho ST, Nastari PM, Lucon O (2004) Ethanol learning curve — the Brazilian experience. Biomass Bioenerg 26:301-304. https://doi.org/10.1016/S0961-9534(03)00125-9

Hanssen SV, Daioglou V, Steinmann ZJN, Frank S, Popp A, Brunelle T, Lauri P, Hasegawa T, Huijbregts MAJ, Van Vuuren DP (2020a) Biomass residues as twenty-first century bioenergy feedstock-a comparison of eight integrated assessment models. Clim Change 163(3):1569-1586. https://doi. org/10.1007/s10584-019-02539-x

Hanssen SV, Daioglou V, Steinmann ZJN, Doelman JC, Van Vuuren DP, Huijbregts MAJ (2020b) The climate change mitigation potential of bioenergy with carbon capture and storage. Nat Clim Chang. https://doi.org/10.1038/s41558-020-0885-y

Hasegawa T, Fujimori S, Havlík P, Valin H, Bodirsky BL, Doelman JC, Fellmann T, Kyle P, Koopman JFL, Lotze-Campen H, Mason-D’Croz D, Ochi Y, Pérez Domínguez I, Stehfest E, Sulser TB, Tabeau A, Takahashi K, Takakura J, van Meijl H, ... Witzke P (2018) Risk of increased food insecurity under stringent global climate change mitigation policy. Nat Clim Change 8(8) 699-703. https://doi.org/10.1038/s41558-018-0230-x

Havlik P, Valin H, Herrero M, Obersteiner M, Schmid E, Rufino MC, Mosnier A, Thornton PK, Bottcher H, Conant RT, Frank S, Fritz S, Fuss S, Kraxner F, Notenbaert A (2014) Climate change mitigation through livestock system transitions. Proc Natl Acad Sci 111(10):3709-3714. https://doi.org/ 10.1073/pnas.1308044111

Herreras Martínez S, Koberle A, Rochedo P, Schaeffer R, Lucena A, Szklo A, Ashina S, van Vuuren DP (2015) Possible energy futures for Brazil and Latin America in conservative and stringent mitigation pathways up to 2050. Technol Forecast Soc Change 98. https://doi.org/10.1016/j.techfore.2015. 05.006

Herrero M, Thronton PK, Notenbaert AM, Wood S, Msangi S, Freeman HA, Bossio D, Dixon J, Peters M, van de Steeg J, Lynam J, Parthasarathy Rao P, Macmillan S, McDermott J, Seré C, Rosegrant M (2010) Smart investments in sustainable food production: revisiting mixed crop-livestock systems. Science 327(FEBRUARY):822-825

Hunsberger C, Bolwig S, Corbera E, Creutzig F (2014) Livelihood impacts of biofuel crop production: implications for governance. Geoforum 54:248-260. https://doi.org/10.1016/j.geoforum.2013.09.022

IEA (2020) World energy balances: overview. https://www.iea.org/reports/world-energy-balances-overv iew

INPE (2017) Projeto PRODES. MONITORAMENTO DA FLORESTA AMAZÔNICA BRASILEIRA POR SATÉLITE. http://www.obt.inpe.br/prodes/index.php

IPCC (2014) WG III Assessment Report 5. http://www.ipcc.ch/report/ar5/wg3/

IPCC (2019) Summary for Policymakers. In J. M. P.R. Shukla, J. Skea, E. Calvo Buendia, V. MassonDelmotte, H.- O. Pörtner, D. C. Roberts, P. Zhai, R. Slade, S. Connors, R. van Diemen, M. Ferrat, E. Haughey, S. Luz, S. Neogi, M. Pathak, J. Petzold, J. Portugal Pereira, P. Vyas, E. Huntley, K. Kissick, (Ed.), Climate change and land: an IPCC special report on climate change, desertification, land degradation, sustainable land management, food security, and greenhouse gas fluxes in terrestrial ecosystems. https://www.ipcc.ch/srccl/chapter/summary-for-policymakers/ 
KC S, Lutz W (2017) The human core of the shared socioeconomic pathways: Population scenarios by age, sex and level of education for all countries to 2100. Glob Environ Chang 42 181-192. https:// doi.org/10.1016/j.gloenvcha.2014.06.004

Klein BC, Chagas MF, Watanabe MDB, Bonomi A, MacielFilho R (2019) Low carbon biofuels and the New Brazilian National Biofuel Policy (RenovaBio): a case study for sugarcane mills and integrated sugarcane-microalgae biorefineries. Renew Sustain Energy Rev 115(February):109365. https://doi.org/10.1016/j.rser.2019.109365

Köberle AC (2019) The value of BECCS in IAMs: a review. Curr Sustainab/renewab Energ Rep 6(4):107-115. https://doi.org/10.1007/s40518-019-00142-3

Köberle AC, Garaffa RSB, Cunha Rochedo PR, Lucena AF, Szklo A, Schaeffer R (2018) Are conventional energy megaprojects competitive? Suboptimal decisions related to cost overruns in Brazil. Energy Policy 122 689-700. https://doi.org/10.1016/j.enpol.2018.08.021

Köberle AC, Rochedo PR, Lucena APF, Szklo A, Schaeffer R (2020) Brazil emissions trajectories in a wellbelow 2oC world: the role of disruptive technologies versus land-based mitigation in an already lowemission energy system. Clim Change 162:1823-1842. https://doi.org/10.1007/s10584-020-02856-6

Köberle A, Rochedo P, Portugal-Pereira J, Szklo A S, de Lucena AFP, Schaeffer R (2015) Brazil Chapter. In T. Spencer \& R. Pierfedericci (Eds.), Beyond the numbers: understanding the transformation induced by INDCs. A Report of the MILES Project Consortium (Issue October, pp. 34-45). http://www.iddri.org/Publications/Beyond-the-numbers-Understanding-the-transformation-induc ed-by-INDCs

Krey V, Guo F, Kolp P, Zhou W, Schaeffer R, Awasthy A, Bertram C, de Boer H-S, Fragkos P, Fujimori S, He C, Iyer G, Keramidas K, Köberle AC, Oshiro K, Reis LA, Shoai-Tehrani B, Vishwanathan S, Capros P, ... van Vuuren DP (2019) Looking under the hood: a comparison of techno-economic assumptions across national and global integrated assessment models. Energy 172 https://doi.org/ 10.1016/j.energy.2018.12.131

Langholtz M, Busch I, Kasturi A, Hilliard MR, Mcfarlane J, Tsouris C, Mukherjee S, Omitaomu OA, Kotikot SM, Allen-dumas MR, Derolph CR, Davis MR, Parish ES (2020) The economic accessibility of CO 2 sequestration through bioenergy with carbon capture and storage ( BECCS ) in the US. Land 9(9):299. https://doi.org/10.3390/land9090299

Leblanc F, Brunelle T, Dumas P, Bibasz R, Pelletierx C, Prudhomme R (in review). Implications of largescale bioenergy deployment on energy demand and agricultural supply: an inter-sectoral perspective from the Imaclim-NLU model. This Issue

Lovejoy TE, Nobre C (2019) Amazon tipping point: last chance for action. Sci Adv 5(12). https://doi.org/10. $1126 /$ sciadv.aba2949

Lucena AFP, Clarke L, Schaeffer R, Szklo A, Rochedo PRR, Nogueira LPP, Daenzer K, Gurgel A, Kitous A, Kober T (2016) Climate policy scenarios in Brazil: a multi-model comparison for energy. Energy Economics 56:564-574. https://doi.org/10.1016/j.eneco.2015.02.005

MAPA (2013) Projeções do Agronegócio: Brasil 2012/2013 a 2022/2023. http://www.agricultura.gov.br/ arq_editor/projecoes - versao atualizada.pdf

Matzenberger J, Kranzl L, Tromborg E, Junginger M, Daioglou V, Sheng Goh C, Keramidas K (2015) Future perspectives of international bioenergy trade. Renew Sustain Energy Rev 43:926-941. https:// doi.org/10.1016/j.rser.2014.10.106

Mazzone A, Cruz T, Bezerra P (2021) Firewood in the forest: Social practices, culture, and energy transitions in a remote village of the Brazilian Amazon. Energy Res Soc Sci 74 101980. https://doi.org/10. 1016/j.erss.2021.101980

MCTIC (2016) Estimativas Anuais de Emissões de Gases de Efeito Estufa no Brasil. http://sirene.mcti.gov. br/documents/1686653/1706227/LIVRO_MCTIC_EstimativaDeGases_Publicação_210x297mm_ FINAL_WEB.pdf/61e78a4d-5ebe-49cd-bd16-4ebca30ad6cd

Meller L, van Vuuren DP, Cabeza M (2015) Quantifying biodiversity impacts of climate change and bioenergy: the role of integrated global scenarios. Reg Environ Change 15(6):961-971. https://doi.org/10. 1007/s10113-013-0504-9

Nepstad D, Soares-Filho BS, Merry F, Lima A, Moutinho P, Carter J, Bowman M, Cattaneo A, Rodrigues H, Schwartzman S, McGrath DG, Stickler CM, Lubowski R, Piris-Cabezas P, Rivero S, Alencar A, Almeida O, Stella O (2009) The end of deforestation in the Brazilian Amazon - Supporting online material (SOM). Science (New York, NY) 326(5958):1-28. https://doi.org/10.1126/science.1182108

Octaviano C, Paltsev S, Gurgel AC (2014) Climate change policy in Brazil and Mexico: Results from the MIT EPPA model. Energy Economics 56:600-614. https://doi.org/10.1016/j.eneco.2015.04.007

OECD-FAO (2015) OECD-FAO Agricultural Outlook 2015. https://doi.org/10.1787/agr_outlook-2015-en

Popp A, Calvin K, Fujimori S, Havlik P, Humpenöder F, Stehfest E, Bodirsky BL, Dietrich JP, Doelmann JC, Gusti M, Hasegawa T, Kyle P, Obersteiner M, Tabeau A, Takahashi K, Valin H, Waldhoff S, 
Weindl I, Wise M, ... Vuuren DP va (2017) Land-use futures in the shared socio-economic pathways. Glob Environ Chang 42 331-345. https://doi.org/10.1016/j.gloenvcha.2016.10.002

Rochedo PRR, Filho BS, Viola E, Schaeffer R, Szklo A, Lucena AFP, Köberle A, Davis JL, Rajão R, Rathmann R (2018) The threat of political bargaining to climate mitigation in Brazil. Nature Clim Change

Rogelj J, Shindell D, Jiang K, Fifita S, Forster P, Ginzburg V, Handa C, Kheshgi H, Kobayashi S, Kriegler E, Mundaca L, Séférian R, Vilariño MV (2018) Mitigation Pathways Compatible with $1.5^{\circ} \mathrm{C}$ in the Context of Sustainable Development. In Masson-Delmotte V, Zhai P, Pörtner H-O, Roberts D, Skea J, Shukla PR, Pirani A, Moufouma-Okia W, Péan C, Pidcock R, Connors S, Matthews JBR, Chen Y, Zhou X, Gomis MI, Lonnoy E, Maycock T, Tignor M, Waterfield T (Eds.) Global Warming of $1.5^{\circ} \mathrm{C}$. An IPCC Special Report on the impacts of global warming of $1.5^{\circ} \mathrm{C}$ above pre-industrial levels and related global greenhouse gas emission pathways, in the context of strengthening the global response to the threat of climate change,. https://www.ipcc.ch/sr15/chapter/2-0/

Rogelj, Joeri, Shindell, D., Jiang, K., \& Al., E. (2018). Mitigation pathways compatible with $1.5^{\circ} \mathrm{C}$ in the context of sustainable development. In V. Masson-Delmotte, P. Zhai, H. O. Pörtner, D.Roberts, J. Skea, P. R. Shukla, A. Pirani, W. Moufouma-Okia, C. Péan, R. Pidcock, S. Connors, J. B. R. Matthews, Y. Chen, X. Zhou, M. I. Gomis, E. Lonnoy, T. Maycock, M. Tignor, \& T. Waterfield (Eds.), Global warming of $1.5^{\circ} \mathrm{C}$. An IPCC Special Report on the impacts of global warming of $1.5^{\circ} \mathrm{C}$ above pre-industrial levels and related global greenhouse gas emission pathways, in the context of strengthening the global response to the threat of climate change. http://www.ipcc.ch/report/sr15/

Rose SK, Popp A, Fujimori S, Havlik P, Weyant J, Wise M, van Vuuren D, Brunelle T, Cui Y, Daioglou V, Frank S, Hasegawa T, Humpenöder F, Kato E, Sands RD, Sano F, Tsutsui J, Doelman J, Muratori M, Prudhomme R, Wada K, Yamamoto H, 2021. Global biomass supply modeling for long-run management of the climate system, Climatic Change, this issue.

Rose SK, Bauer N, Popp A, Weyant J, Fujimori S, Havlik P, Wise M, van Vuuren DP (2020) An overview of the Energy Modeling Forum 33rd study: assessing large-scale global bioenergy deployment for managing climate change. Clim Change 163(3):1539-1551. https://doi.org/10.1007/s10584-020-02945-6

Rose SK, Kriegler E, Bibas R, Calvin K, Popp A, van Vuuren DP, Weyant J (2014) Bioenergy in energy transformation and climate management. Clim Change 123(3-4):477-493. https://doi.org/10.1007/ s10584-013-0965-3

Rose SKR, Glub AA, Sohngen B (2013) Total factor and relative agricultural productivity and deforestation. Amer J Agr Econ 95(2):426-434. https://doi.org/10.1093/ajae/aas113

Rua Rodriguez Rochedo P (2016) Development of a global integrated energy model to evaluate teh Brazilian role in climate change mitigation scenarios [Universidade Ederal do Rio de Janeiro]. http://ppe.ufrj. br/ppe/production/tesis/pedro_rochedo.pdf

Salina FH, de Almeida IA, Bittencourt FR (2020) RenovaBio Opportunities and Biofuels Outlook in Brazil. In Sayigh A (Ed.), Renewable Energy and Sustainable Buildings: Selected Papers from the World Renewable Energy Congress WREC 2018 (pp. 391-399). Springer International Publishing. https:// doi.org/10.1007/978-3-030-18488-9_30

Searchinger T, Edwards R, Mulligan D, Heimlich R, Plevin R (2015) Do biofuel policies seek to cut emissions by cutting food? Science 347(6229):1420-1422. https://doi.org/10.1126/science.1261221

SEEG (2019) Total Emissions by Sector. Sistema de Estimativas de Emissões e Remoções de Gases de Efeito Estufa (SEEG). http://plataforma.seeg.eco.br/total_emission. Accessed 27 Dec 2021.

de Silva RO, Barioni LG, Hall JAJ, Moretti AC, Fonseca Veloso R, Alexander P, Crespolini M, Moran D (2017) Sustainable intensification of Brazilian livestock production through optimized pasture restoration. Agricultural Systems 153:201-211. https://doi.org/10.1016/j.agsy.2017.02.001

Smith P (2013) Delivering food security without increasing pressure on land. Glob Food Sec 2(1):18-23. https://doi.org/10.1016/j.gfs.2012.11.008

Soares-filho B, Rajão R, Macedo M, Carneiro A, Costa W, Coe M, Rodrigues H, Alencar A (2014) Cracking Brazil's Forest Code. Science 344(April):363-364

Soares-Filho B, Rajão R, Merry F, Rodrigues H, Davis J, Lima L, Macedo M, Coe M, Carneiro A, Santiago L (2016) Brazil's market for trading forest certificates. PLoS ONE 11(4):1-17. https://doi.org/10.1371/ journal.pone.0152311

Sonter LJ, Barrett DJ, Soares-Filho BS, Moran CJ (2014) Global demand for steel drives extensive land-use change in Brazil's Iron Quadrangle. Glob Environ Chang 26(1):63-72. https://doi.org/10.1016/j.gloen vcha.2014.03.014 
Strassburg BBN, Latawiec AE, Barioni LG, Nobre CA, da Silva VP, Valentim JF, Vianna M, Assad ED (2014) When enough should be enough: Improving the use of current agricultural lands could meet production demands and spare natural habitats in Brazil. Global Environmental Change 28:84-97. https://doi.org/10.1016/j.gloenvcha.2014.06.001

Tagomori IS, Rochedo PRR, Szklo A (2019) Techno-economic and georeferenced analysis of forestry residues-based Fischer-Tropsch diesel with carbon capture in Brazil. Biomass Bioenerg 123(February):134-148. https://doi.org/10.1016/j.biombioe.2019.02.018

USDA (2020) USDA Agricultural Projections to 2029. https://www.ers.usda.gov/webdocs/outlooks/95912/ oce-2020-1.pdf? $v=789.5$

van Ruijven BJ, Levy MA, Agrawal A, Biermann, F, Birkmann J, Carter TR, Ebi KL, Garschagen M, Jones B, Jones R, Kemp-Benedict E, Kok M, Kok K, Lemos MC, Lucas PL, Orlove B, Pachauri S, Parris TM, Patwardhan A, ... Schweizer VJ (2013) Enhancing the relevance of Shared Socioeconomic Pathways for climate change impacts, adaptation and vulnerability research. Climatic Change 122(3) 481-494. https://doi.org/10.1007/s10584-013-0931-0

Publisher's Note Springer Nature remains neutral with regard to jurisdictional claims in published maps and institutional affiliations.

\section{Authors and Affiliations}

\section{Alexandre C. Köberle ${ }^{1,2}$. Vassilis Daioglou ${ }^{3,4} \cdot$ Pedro Rochedo $^{2} \cdot$ André F. P. Lucena $^{2}$. Alexandre Szklo ${ }^{2}$. Shinichiro Fujimori ${ }^{5,6}$. Thierry Brunelle ${ }^{7}$. Etsushi Kato ${ }^{8}$. Alban Kitous $^{9} \cdot$ Detlef P. van Vuuren ${ }^{3,4} \cdot$ Roberto Schaeffer $^{2}$}

1 Grantham Institute for Climate Change and the Environment, Imperial College London, London, UK

2 Centre for Energy and Environmental Economics, Energy Planning Programme, Universidade Federal Do Rio de Janeiro, Rio de Janeiro, Brazil

3 PBL Netherlands Environmental Assessment Agency, PO Box 30314, The Hague, The Netherlands

4 Copernicus Institute of Sustainable Development, Utrecht University, Princetonlaan 8a, 3584 CB Utrecht, the Netherlands

5 Department of Environmental Engineering, Kyoto University, Kyoto, Japan

6 National Institute for Environmental Studies (NIES), Tsukuba, Japan

7 CIRAD, UMR CIRED, 94736 Nogent-sur-Marne, France

8 The Institute of Applied Energy (IAE), Minato, Tokyo 105-0003, Japan

9 European Commission, Joint Research Centre (JRC), Sevilla, Spain 